\title{
Structure, Evolution of the Biosphere and Possible Ways of Noospherogenesis
}

\author{
Alexander A. Protasov* \\ Institute of Hydrobiology \\ of National Academy of Sciences of Ukraine \\ 12 Geroyev Stalingrada av., Kiev, 04210, Ukraine
}

Received 03.03.2016, received in revised form 24.05.2016, accepted 19.07.2016

The biosphere is complex of bioinert systems, the smallest structural unit of which is an ecosystem or biogeocoenosis. The biosphere has a hierarchical structure. Local ecosystems as the elementary units of the biosphere are combined into regional systems of similar ecosystems, which in turn make up biogeomes. The deductive approach to examining the structure of the biosphere is based on the allocation of V.I. Vernadsky life condensations and films in the structure of the biosphere. On this basis 4 biosferomerones are distinguished, including more than ten biogeomes of hydrosphere and land. In accordance with the structure, the development (evolution) of the biosphere is an irreversible succession of its structural elements - from ecosystems to biogeomes. This succession in the history of the biosphere looks like a series of separate states, which are observed or reconstructed on the basis of paleontological, paleoclimatic, geological data. The dynamic evolution system of the biosphere is formed by the trends of evolution as information channels, which determine the nature and direction of development in one or another aspect of evolution-genetic, ecomorphic, ecosystem and other. One of the most "young" trend is anthropo-cultural trend, a manifestation of which in the biosphere is the formation of anthropogenic ecosystems. They include not only alive and bioinert natural elements but also man-made elements. The basis of the noospherogenesis is a change of natural ecosystems by different types of man-made systems - technical, agricultural and urban ecosystems. Modern ecological crisis can be considered as a logical step in the evolution of the biosphere, preceding the transition to its new state - the noosphere.

Keywords: biosphere, evolution, biogeome, biosferomeron, ecosystem, noospherogenesis.

DOI: $10.17516 / 1997-1389-2016-9-3-256-290$.

(c) Siberian Federal University. All rights reserved

* Corresponding author E-mail address: pr1717@ukr.net 


\title{
Структура, эволюция биосферы \\ и возможные пути ноосферогенеза
}

\author{
А.А. Протасов \\ Институт гидробиологии \\ Национальной академии наук Украинь \\ Украина, 04210, Киев, пр. Героев Сталинграда, 12
}

$\overline{\text { Биосфера представляет собой сложную биокосную систему, структурной единицей которой }}$ является экосистема, биогеоценоз. Биосфера имеет иерархическую структуру. Элементарные единицы биосферы - локальные экосистемы - объединяются в региональные комплексы однотипных экосистем, которые, в свою очередь, составляют биогеомы. Дедуктивный подход в рассмотрении структуры биосферы строится на выделении В.И. Вернадским сгущений жизни и пленок в биосфере. На этой основе выделяют четыре биосферомерона, включающих в себя более десяти биогеомов гидросферы и суши. В соответствии со структурой развитие биосферы, её эволючия представляют собой необратимую последовательную смену её структурных элементов - от экосистем до биогеомов, изменений связей между ними. Эта смена выглядит в истории биосферы как серия отдельных наблюдаемых или реконструированных на основании палеонтологических, палеоклиматических, геологических данных состояний. Динамическую эволюиионную систему биосферы образуют тренды эволючии, информачионные каналь, которые определяют характер и направленность развития в том или ином аспекте эволюиии, - генетический, экоморфный, экосистемный и другиеканалы-тренды. Однимиз наиболее «молодых» трендов считается антропокультурный тренд, проявлением которого в биосфере служит формирование антропогенных экосистем. Они включают не только живые и биокосные природные элементы, но и созданные человеком. В основе ноосферогенеза лежит смена природных экосистем антропогенными системами различных типов - техно-, агро- и урбоэкосистемами. Современный экологический кризис может рассматриваться как закономерный этап эволюиии биосферы, предшествуюший переходу кеё новому состоянию - ноосфере.

Ключевые слова: биосфера, эволюиия, биогеом, биосферомерон, экосистема, ноосферогенез.

\section{Вступление}

Несмотря на популярность проблем эволюции, многие вопросы биосферологии именно в плане эволюции биосферы остаются весьма спорными. В частности, далеко неоднозначно трактуется вопрос об иерархической структуре, основных единицах биосферы и их развитии. За проблемой эволюции биосферы чаще всего стоят описания истории жизни на нашей планете. В то же время биосфера - это биокосная система взаимодействующих живых и неживых элементов. Минимальной структурной единицей биосферы является экосистема, биогеоценоз (ТимофеевРесовский, Тюрюканов, 1966; Протасов, 2012).

Цель данной работы - рассмотреть концепцию структуры биосферы, используя ве- 
дущие положения учения В.И. Вернадского, её эволюцию, включая некоторые модели ноосферогенеза, на основе предлагаемой концепции эволюционной системы биосферы.

\section{Биосфера}

Во второй половине XIX в. сложились представления о геологических оболочках Земли, но модель строения планеты еще не была завершена. Геологу, а не исследователям живого принадлежали следующие слова: «...жизнь ограничена определенной зоной на поверхности литосферы... и на поверхности материков можно выделить самостоятельную биосферу» (Зюсс, 1875 (цит. по: Кафанов, 2005, c. 74)).

Согласно В.И. Вернадскому, «биосфера может рассматриваться как область земной коры, занятая трансформаторами, переводящими космическое излучение в действенную земную энергию» (Живое вещество..., 1994, c. 321). Таким образом, биосфера в его представлении - это как «область жизни», так и живые организмы, обитающие в этой области. Совокупность всего живого на планете рассматривалась В.И. Вернадским как «живое вещество». Понятие живого вещества имеет смысл только в глобальном масштабе. При изменении этого масштаба рассмотрения живое вещество начинает «дробиться», дифференцироваться на биомы, сообщества, консорции, симбиотические комплексы, наконец, на отдельные организмы. Область земной коры, «занятая трансформаторами энергии», неоднородна по условиям, по количеству, массе и продукции «трансформаторов», т.е. живых существ, и по их составу.

Сама идея совокупной роли живого в планетарном масштабе, что называется, «носилась в воздухе» в первом-втором десятилетиях XX в. В 1920-х гг. выдающийся биолог и разносторонний эколог В.Н. Беклемишев, взяв сам термин у К.Д. Старынкевича, всю совокупность живого рассматривал как «Геомериду». Он так представлял её структуру: «Геомерида, этот копошащийся безбрежный мир живого, устроена подобно структуре нашего тела: она слагается из отдельных частей - всевозможных биоценозов разного порядка» (Беклемишев, 1994, с. 61-62).

Одна из наиболее ярких метафор, связанных со строением биосферы, принадлежит ему же (1994, с. 5): «...совокупность организмов, эта живая кора, распростертая на каменном шаре». За ней мы видим два основных элемента - «каменный шар» как символ всего, что может быть обозначено как «ГЕО», и «живую кору», что можно связать с «БИО». Основной чертой организации этой «живой коры» является непрерывное сохранение типичных форм целого при постоянной смене его частей.

Живой покров Земли меристичен, состоит из определенных элементов, но в то же время и целостен, представляет собой единство всего живого. В.Н. Беклемишев принял термин «Гео-мерида» (от греч. мерос-часть), но мог использовать и частицу «-холида» (от греч. холос - целый, целостный). Исходя из этого были предложены термины «биохолида» и «геохолида», в которых подчеркивается целостность как живого, так и среды его существования (Протасов, 2012). Биохолида определенным образом структурирована, имеет иерархическое строение, поскольку особи, сообщества обладают «самонедостаточностью», ассоциативность организмов одно из их важнейших свойств живого.

Под геохолидой следует понимать косное и биокосное вещество биосферы, обеспечивающее существование живых организмов, непосредственно связанное с живыми существами; это и обитаемое пространство для биохолиды, всего живого. Геохолида также 
имеет определенную структуру, свои подразделения. Жизнедеятельность особи связана с её ближайшим жизненным пространством, сообщество организмов обитает в определенном биотопе, ареал вида ограничен определенным, приемлемым для этого вида набором факторов среды в определенном планетарном пространстве.

Собственно, та область биосферы, которая является вместилищем жизни (геохолида), становится особой частью геологических оболочек Земли только во взаимосвязи с жизнью, с её проявлениями, с живым веществом (биохолидой). На Марсе также существует своя литосфера, атмосфера, но они только физические объекты, в них не проявляются свойства «марсохолиды», поскольку они не связаны (как пока нам известно) с проявлениями жизни. Именно поэтому объем, протяженность геохолиды определяются не физическими или геологическими факторами, а степенью их связи с жизнью.

В.И. Вернадский подчеркивал, что биосфера представляет собой сложную динамическую систему. Он писал: «Сама биосфера не является случайным образованием - она отвечает определенной форме организованности. Это устойчивая динамическая система, равновесие, установившееся в основных чертах своих с самого своего начала» (Живое вещество..., 1994, с. 456).

Биосфера - сложная система, а не только область жизни или, напротив, только совокупность живого. Это положение было обобщено Р. Маргалефом: «...совокупность живых организмов Земли, рассматриваемая как некая целостность, локализованная в области интенсивного взаимодействия атмосферы, гидросферы и литосферы, где живые и неживые компоненты включены в состав единой динамической системы»» (Маргалеф, 1992, c. 11).

\section{Структура биосферы}

Биосфера как биокосная система имеет свою структуру, свои элементы. «Неделимыми» биосферы являются экосистемы. Но как организм не состоит непосредственно из различных клеток, так и биосфера не может быть простой суммой локальных экосистем. Первый шаг от общего к частному в рассмотрении структуры биосферы сделал В.И. Вернадский, утверждая, что в основу её «должна быть положена густота жизни - выделения участков, ею обогащенных» (Живое вещество..., 1994, с. 382). Он вводит важные для рассмотрения всей структуры биосферы понятия сгущения жизни и пленок жизни, которые «образуют в океане области наибольшей трансформации солнечной энергии» (Там же, с. 383).

При средней глубине Мирового океана около 4000 м фотическая зона пелагиали занимает всего около 100-200 м, и она может рассматриваться как поверхностная пленка в океане. Вторая пленка - донная, в ней происходят в основном процессы деструкции и высвобождения биогенных веществ.

Две пленки, о которых писал В.И. Вернадский, - поверхностная и донная - у берегов океана сходятся и образуют прибрежное сгущение. Это сгущение представляет собой континентальный контур океанов, где происходят важные процессы массообмена между материками и гидросферой. В настоящее время разработана целостная концепция контурных биотопов и экосистем моря (Зайцев, 2015; Zaitsev, 2012).

Контурные биотопы представляют собой пограничные местообитания. Это разделы фаз - жидкой и газообразной (водная масса и атмосфера), жидкой и твердой (водная масса и разнообразные твердые субстраты, биотопы на границе донных отложений и водной толщи (Протасов, 2011). 
Впервые В.И. Вернадский обратил внимание на существование между двумя «основными» пленками - поверхностной и донной огромных масс воды, в которых отсутствуют мощные сгущения, подобные краевым. «B $x u$ мизме океана поверхностная часть может рассматриваться как активная, а остальная масса воды - как биохимически слабо деятельная. Исходя из этого ясно, что едва ли $2 \%$ общей массы океана заняты сгущениями жизни. Вся остальная масса содержит жизнь рассеянную», - делает вывод В.И. Вернадский (2012, с. 231).

Переходя к сгущениям и пленкам жизни на суше, В.И. Вернадский отмечает меньшую сложность системы для последней: «...no cyществу, мы имеем здесь одну живую пленку, которую представляют почва и населяющая её фауна и флора» (с. 235).

Таким образом, биосфера Вернадского в самом общем виде есть система, которая состоит в океане из поверхностной зоны океана (пленки), где происходит трансформация солнечной энергии фотосинтетиками, донной пленки, в которой идет трансформация и аккумуляция органических и минеральных веществ, достаточно инертной промежуточной между ними зоны, а также прибрежного, шельфового сгущения, где все геохимические процессы активизируются в связи с контактом океана и суши. На континентах существует одна почвенная пленка жизни, её дополняют разнообразные по своему строению сгущения в континентальных водах.

\section{Сгущения и биосферомероны}

Сгущения жизни существуют в тех областях в биосфере, где сочетания условий для продуцирования органического вещества наиболее благоприятны. Граничные области и контурные экосистемы, как правило, становятся местом таких сгущений (Айзаттулин, Лебедев, Хайлов, 1979; Зайцев, 2015).

Сгущения и пленки, которые выделил В.И. Вернадский, могут рассматриваться как наиболее крупные части, подразделения биосферы - биосферомероны (Протасов, 2013a). Но и самая большая область жизни в биосфере, в которой не наблюдается сгущения, афотическая зона океана также должна быть выделена в отдельный биосферомерон (рис. 1).

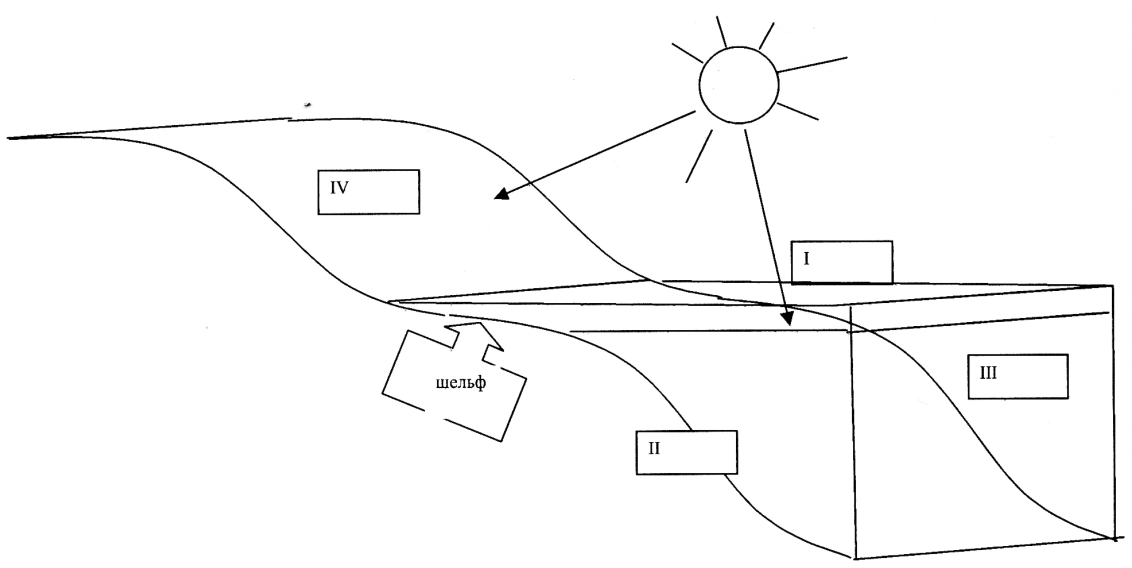

Рис. 1. Схема структуры биосферы и её биосферомеронов на основе сгущений жизни и пленок, по В.И. Вернадскому. Биосферомероны: I - поверхностной пленки океана; II - донной пленки; III - промежуточный; IV - наземной пленки жизни 
Пространство, в котором обитает и функционирует вся совокупность живых организмов, представляет собой их совокупное жизненное пространство. Понятие ближайшего жизненного пространства (БЖП) ввели в экологию известный эколог и гидробиолог К.М. Хайлов и его ученики (Хайлов и др., 1992). Оно часть бесконечной окружающей среды, которая непосредственно контактирует с организмом и в которой происходят реальные процессы связи организма со средой. Расчеты показывают (Протасов, 2013a), что концентрация живого вещества в единице объема жизненного пространства наибольшая на суше, в наземном биосферомероне. Наибольший вклад в общую массу живого вещества вносят леса, в первую очередь тропические дождевые. Концентрация жизни в пелагическом биосферомероне (экосистемы водной толщи океанов) в миллион раз меньше, чем на суше. Эта неоднородность распределения жизни - важный аспект разнообразия биосферы: скудный жизнью III биосферомерон (рис. 1) есть колоссальное депо биогенных элементов (объем около $1,3 \cdot 10^{9} \mathrm{\kappa m}^{3}$ ), без которых «фотосинтетическая продукционная машина» экосистем I биосферомерона на могла бы работать. Океан (II и III биосферомероны) является неисчерпаемым благодаря глобальным процессам гидрологического цикла источником воды для IV биосферомерона. В то же время поверхностный сток с материков постоянно пополняет запасы биогеонов в гидросфере, в частности такого важного элемента, как фосфор.

Однако общесистемные представления об иерархической структуре биосферы заставляют нас поставить вопрос и о структуре биосферомеронов. Внутренне они неоднородны, по-своему организованы. Так, I и III биосферомероны, по сути, единая система, объединенная потоками вещества и энергии.
Океанический планктон совершает масштабные вертикальные миграции, объединяя поверхностные и глубинные водные массы, население представлено сходными жизненными формами. Существуют и физические явления, определяющие масштабные горизонтальные и вертикальные перемещения водных масс. Это единая система локальных разномасштабных пелагических экосистем.

Наземный (эпигейный) биосферомерон неоднороден, в первую очередь в связи с географической зональностью, которая является как следствием неравномерности получения солнечной энергии на поверхности геоида, так и взаимодействия континентов, атмосферы и Мирового океана.

Совокупность экосистем в океане, составляющих соответствующие биосферомероны, весьма разнородна по своей структуре, источникам энергии, круговоротам вещества. Кроме пелагического океанического, донного батиально-абиссального и шельфового комплексов экосистем (в I и III биосферомеронах), необходимо выделить еще два специфических в океаносфере комплекса экосистем, поскольку составляющие их экосистемы совершенно уникальны. Это биогермовые (в настоящее время - коралловые) и гидротермально-сиповые экосистемы.

\section{Экосистема как элементарный структурно-функциональный элемент биосферы}

Понятие экосистемы, как известно, было введено А. Тэнсли (Tansley, 1935), однако существуют и другие близкие понятия и термины. Так, в своем обзоре, связанном с биогеоценозом и экосистемой, В.Н. Сукачев (1972) приводит более десятка близких по значению терминов.

Как известно, А. Тэнсли рассматривал экосистемы как целостные комплексы, 
включающие не только организмы, но также комплекс факторов среды их существования в самом широком смысле. Эти системы он считал основными природныли единицами лика Земли. Хотя существуют представления о тождественности понятий «экосистема» и «биогеоценоз»: «экосистема - основной объект биогеоценологии» (Бурковский, 2006, с. 3), следует все-таки согласиться с А.И. Кафановым (2005) в том, что «...в отличие от «экосистемы», являющейся функциональным понятием, «биогеоценоз» - понятие собственно биохорологическое» (с. 87).

Экосистема и биогеоценоз - понятия близкие, но не идентичные. Согласимся с Г.Г. Винбергом (Переписка..., 2013), что экосистема в смысле Эванса (Evans, 1956) чаще всего не отражает свойств её как части, элемента биосферы, но необходимо считаться и с реальным разнообразием биокосных систем. В качестве компромисса нами было предложено понятие экосистемно-биогеоценотического градиента (Протасов, 2014a). На одном полюсе следует расположить экосистемы, для которых сложно, либо вообще невозможно, либо нецелесообразно установление границ в хорологических рамках ландшафтов. Таковы многие техноэкосистемы, где основными косными элементами выступают различные антропогенные и техногенные объекты. На другом полюсе - биогеоценозы, реальные элементы живого функционирующего покрова Земли. Все большее и большее значение имеют в структуре биосферы такие антропогенные экосистемы, как агро- и урбоэкосистемы, они в этом градиенте занимают, вероятно, среднее, промежуточное, положение.

Пространственные границы биосферы связаны с распространением биогеоценозов - экосистем. В горизонтальном (скорее, если можно так выразиться, сферическом, геоидальном) измерении это почти вся по- верхность Земли. В вертикальном на суше нижние слои тропосферы, которые непосредственно участвуют в газообмене с почвой, растительностью, животными, и ограниченные распространением водоносных слоев в грунтах. Что касается гидросферы, то здесь населена вся масса воды и верхний слой (порядка первых десятков сантиметров или метров) донных отложений.

Любая система ограничена, за её пределами - среда существования, однако значительную часть этой среды для современных экосистем представляют другие взаимодействующие с ней экосистемы.

\section{Биогеом и его место в структуре биосферы}

При географическом подходе в основе структуры живого покрова Земли лежит понятие ландшафта. Каждому ландшафту присущ свой облик, сочетание его элементов неповторимо. Именно поэтому Л.С. Берг (1947) рассматривал ландшафты как «географические индивиды», или «особи». Это подводит нас к некоторым аналогиям: если особи, живые организмы, обладающие безусловной индивидуальностью, тем не менее, объединяются в популяции, то можно, видимо, говорить о «популяциях» географических ландшафтов? Популяция организмов, как известно, представляет собой «совокупность особей одного вида, обладающих общим генофондом и занимающих определенную территорию» (Биологический..., 1986, с. 499). Другими словами, при всех индивидуальных отличиях (что создает внутреннее разнообразие популяции) все особи относятся к одному виду, т.е. имеют важные признаки сходства. Одновидовые популяции в своей совокупности занимают видовой ареал.

Рассматривая понятия экосистемы, с одной стороны, биохолиды и связанной с ней 
геохолиды - с другой, мы видим реальные системы, которые занимают как бы «полярные» положения. Полюса эти таковы: на одном биоценоз, реальное, конкретное сообщество организмов, на другом - биохолида, живое вещество планеты; и другая пара: биотоп, комплекс условий среды, местообитания, с которым связано сообщество, и геохолида как совокупность всех земных факторов, поддерживающих жизнь. Тогда закономерно возникает вопрос: что за структуры в этой иерархии находятся «между» полярными системами живого и косного?

Богатство экосистем как элементов биосферы огромно, при этом резко доминирующая роль какой-либо из них не выражена, т.е., в целом их совокупность обладает высоким разнообразием. Однако существует и другая закономерность: «общая конструкция» экосистем довольно типична; в сходных условиях (сходство ГЕО) сходными оказываются и биологические структуры надорганизменного уровня (сходство БИО). Таким образом, на фоне широкой дивергенции, разнообразия существуют предпосылки конвергентного сходства.

Именно процессы дивергенции и конвергенции создают необходимый баланс оптимального разнообразия биологических систем: процессы дивергенции имеют «центробежную» природу, обеспечивают увеличение многообразия приспособлений, форм; конвергенции, напротив, ограничивают разнообразие, закрепляют оптимальные в данных условиях формы и системы. Эти процессы существуют на всех уровнях организации живых и биокосных систем.

Как пример конвергенции может быть упомянута концепция параллельных сообществ (Кузнецов, 1980; Thorson, 1960). В соответствии с принципами зональности распределения живых организмов по поверхности
Земли (Вальтер, 1975; Кафанов, 2004) сходные фитоценозы, ландшафты имеют вполне закономерное зональное распространение. На континентах выражена широтная зональность, которая в менее четкой форме присутствует и в океане.

Именно представления о сходстве сообществ были положены в основу понятия биома (сам термин был введен в экологическую науку американским ботаником и экологом Ф. Клементсом в 1916 г.). Приводится определение биома как «базового блока сообществ, basic community unit» (Clements, Shelford, 1939, c. 20). Определение недостаточно четкое, что позволило впоследствии широко трактовать само понятие и термин. Биом - это, скорее, тип сообществ с достаточно обобщенным составом, характерными процессами обмена веществ, сукцессии.

На суше в масштабах континентов распределение тех или иных типов растительности, а значит и биогеоценозов, облик которых растительность в основном и определяет, связывают с соотношением температуры и влажности (Риклефс, 1979; Уиттекер, 1980). Определенному сочетанию условий соответствует определенная группа или класс экосистем.

Для уточнения понятийного аппарата в этой области экологии и биосферологии был предложен термин «биогеом», в котором объединены как биоценотические, так и средовые характеристики групп сходных по своему характеру экосистем (Протасов, 2012, 2013a). За понятием «биом» следует оставить обобщенную характеристику сходных по своему характеру биоценозов. Экосистемы, входящие в биогеомы, могут быть условно разделены на три типа - «биотический», «олигобиотический» и «суббиотический»1. Такое деление,

Эти названия имеют отношение лишь к условной степени представленности живых или косных элементов, но не к собственно структуре экосистем. 
основанное на большей или меньшей значимости биотической или абиотической физиономических составляющих, позволяет рассматривать в единой классификации наземные и водные экосистемы, а следовательно, и их совокупности - биогеомы.

К первому типу можно отнести экосистемы с явно выраженной, эдифицирующей ролью биотических компонентов. Это лесные экосистемы на суше, коралловые биогермовые экосистемы в океане. Весь облик, пространственная структура их определяется биотическими элементами. Экосистемы «олигобиотического» типа (с незначительной степенью биотических «созидающих» факторов) - это экосистемы, в которых биоценоз не имеет определяющей роли в общем облике. К таким можно отнести степные, тундровые экосистемы. Наконец, «суббиотический» тип экосистем характеризуется доминированием элементов и факторов косной природы в формировании общего их облика. Пелагические океанические и экосистемы пустынь могут быть примером таких экосистем.

Мы выделяем пять (шесть) биогеомов суши и семь в гидросфере, которые охватывают практически всю биосферу Земли (Протасов, 2011, 2013а). Следует выделить и некоторые внебиогеомные экосистемы, которые имеют скорее экотонный характер, например мангровые.

Таким образом, структура биосферы имеет иерархический характер: включает экосистемы, биогеомы, биосферомероны.

\section{Принцип хаэссеитас}

В основу рассмотрения как структуры и функционирования биосферы, так и её развития, эволюции должен быть положен системный принцип (Красилов, 1986; Krassilov, 2014). Всякая материальная система, будь то организм или биосфера, является целостной совокупностью характерных для неё элементов, которые взаимодействуют между собой, она занимает определенное пространство и существует в определенном времени (Савинов, 2012).

Одним из свойств организма как дискретной единицы живого является онтогенез - индивидуальное развитие. Даже у вирусов рассматривается определенная смена экоморфных стадий (Алеев, 1986). Очевидно, что организм представляет собой сложную материальную биотическую систему. Сложность её еще больше возрастает, если учитывать, что организм практически всегда существует в виде аутоценоза, т.е. целой системы симбиотически связанных особей (Савинов, 2012). В каждый из моментов своей жизни организм (симбиотическая система) имеет определенную структуру взаимодействующих частей, элементов. Имея представления об онтогенезе других особей этого вида, мы можем делать достаточно уверенный прогноз будущего состояния данной особи. Хотя в конкретных условиях проявляется значительный диапазон пластичности (Алеев, 1986; Дубина, Кордюм, 2015), в целом последовательность возрастных состояний организма в высокой степени предсказуема. Но организм доступен для нашего наблюдения только здесь и сейчас в определенной своей стадии развития, материальная система организма остается относительно неизменной лишь определенное время. Это и есть проявления принципа хаэссеитас (Заварзин, 2007а). Никакого развития как явления мы реально в данный момент не наблюдаем, доступен для наблюдения лишь ряд последовательных состояний системы. На основании сравнительного анализа мы можем сделать некоторые заключения о результатах внутренних процессов в системе и её связей со средой за определенный промежуток времени. Но согласно принципу хаэссеитас за- 
ключения о развитии мы делаем только на основании сравнения ряда последовательных состояний.

Существует нематериальная абстрактная система трендов индивидуального развития системы организма и его состояний (онтогенетическая система), таких трендов может быть выделено несколько. Экоморфный тренд включает определенную последовательность экоморфных стадий и состояний. Можно назвать физиологический, репродуктивный тренды, в соответствии с которыми происходит формирование физиологических и репродуктивных функций. У человека, кроме того, существуют специфические для него ноогенетический и культурный тренды. Для организма, указывал И.И. Шмальгаузен (1968), чрезвычайно важны системы корреляций, или когерентности, процессов развития отдельных частей организма. Это важно как в онтогенезе, так и в процессах эволюционного образования видов. Относительная медленность перестройки этих коррелятивных систем может тормозить прогрессивную эволюцию видов. Совокупности онтогенетических трендов обладают всеми признаками системности: единством и целостностью, когерентностью, пластичностью в каких-то пределах нормы адаптации. Эти тренды заданы вполне материальными факторами: генетической информацией в ДНК данной особи и вида, связями её со средой, другими организмами. Онтогенетическая система организма представляет собой совокупность последовательных состояний развития, объединенных онтогенетическими трендами или информационными каналами.

В экологической сукцессии, индивидуальном развитии экосистем также существует подобная система развития. От «эмбриона» биогеоценоза (Сукачев, 1972) до климакса (Clements, Shelford, 1939) экосистема прохо- дит ряд стадий, ряд состояний, которые мы и можем наблюдать в тот или иной момент. В тех или иных условиях для данного типа экосистем последовательность состояний и стадий достаточно прогнозируема, что позволило ввести понятие сукцессионной системы (Разумовский, 1999), хотя постулируемая им строгая генетическая детерминированность вряд ли всегда реально существует в природе.

В сукцессии присутствует своя система трендов или, как их называет Ю. Одум, тенденций сукцессионного процесса (Odum, 1969; Одум, 1975). Таких трендов он выделяет шесть, а именно: структуры сообществ, энергетики сообществ, жизненных циклов, круговоротов биогенных веществ, давления отбора, гомеостаза. Количество и содержание трендов может быть дополнено и изменено; так, представляется, что следует ввести тренд слаженности, когерентности сукцессионных процессов (Красилов, 1986; Straskraba, 1996). Характеристики трендов вполне определенно и направленно изменяются от ранних стадий сукцессии к климаксу. Так, в энергетическом тренде чистая продукция снижается, а доля энергии, затрачиваемая на поддержание структуры сообществ, возрастает. В структурном тренде богатство элементов сообществ (количество таксонов, экоморф), как и биохимическое разнообразие, возрастает, так же как возрастает и второй компонент разнообразия - выравненность. Возрастает пространственная организованность. Растет продолжительность жизненных циклов, сужается специализация по экологическим нишам. Выражены изменения в тренде общего гомеостаза: развиваются внутриэкосистемные симбиотические отношения, формируются разнообразные симбиотические системы, снижается энтропия системы и возрастает общее количество информации. Но, рассматривая стратегию развития экосистем, 
Ю. Одум почти полностью обходит стороной изменения, происходящие в косной их части. В системе сукцессии должен быть выделен абиотический тренд. Например, в озере в процессе сукцессии могут изменяться гидрохимические параметры, характер донных грунтов и т.п. В целом происходит усложнение косной компоненты экосистемы. Биотическая и косная подсистемы тесно связаны. Одной из жизненных функций является деятельность по упорядочению организации среды, ближайшего жизненного пространства. В силу чего энтропия целостной системы в ходе сукцессии снижается.

Таким образом, сукцессионный процесс представляет собой взаимодействие двух систем - материальной экосистемы в данное время и системы трендов, определяющих характер и направленность изменений. Системный подход обусловливает обширные параллели; так, предлагается рассматривать биогеохимическую сукцессию как основу эволюции биосферы (Заварзин, 2003).

В этом же ключе высказался Р. Маргалеф (2011), утверждая, что «процесс эволюции согласуется с теми же тенденциями, которые направляют и сукцессию». В частности, он указывает, что отношение продукции к биомассе, повышение эффективности и специализации «должны являться общими трендами филогенетических линий» (с. 76). Следует отметить различие между сукцессионным процессом и эволюцией. Сукцессия приводит экосистему к состоянию климакса. В условиях длительной неизменности среды (что, правда, маловероятно) это состояние может продолжаться неограниченно долго. Во всяком случае, оно лишено внутренних предпосылок формирования кризисных ситуаций. В эволюционном процессе кризисные явления представляют собой неизменный элемент развития эволюционной системы.

\section{Синергетика биосферы}

Согласно положениям синергетики (Хакен, 1980; Руденко, 2000; Поярков, Бабаназарова, 2003) биосфера и её структурные элементы могут быть отнесены к открытым, нелинейным, неравновесным системам.

Эти системы могут быть разделены на две группы, в первой из которых они могут находиться в нескольких состояниях: состоянии хаоса, периода самоорганизации, который завершается состоянием неустойчивого равновесия, переходящего к периоду разрушительной хаотизации, возвращающему к состоянию хаоса. Системы второй группы в своем развитии проходят стадию организации, состояние устойчивого равновесия, которое переходит путем созидающей хаотизации опять же к состоянию хаоса. Если принять, а для этого есть все основания, что в первую группу входят живые системы (популяции, сообщества, биомы), а во вторую - элементы геохолиды, то биокосные системы, включая и биосферу, должны обладать некоторыми «синтетическими» свойствами. То есть включать в своем развитии как самоорганизацию, так и организацию, находиться в состоянии «неустойчиво-устойчивого» равновесия. Можно, вероятно, также провести определенные параллели между состояниями хаотизации и периодами некогерентного развития.

\section{Эволюция биосферы}

Очевидно усложнение структуры биосферы в эволюционном времени. Важно отметить, что этот процесс происходил постоянно, однако имел определенные периоды, которые могут быть установлены на основании палеонтологических, геологических данных. Такие эволюционно относительно однородные этапы характеризовались как эволюционнобиологические формации (Колчинский, 1990). Однако представляется, что сужение 
их только до «биологических» неправомерно, скорее, они ближе к формациям «биосферной сукцессии». Так, Г.А. Заварзин выделяет несколько крупных этапов, в которых «новые группировки накладываются на предыдущие как на фундамент» (2003, с. 318). Первый этап был, по сути, добиосферным этапом эволюции геосферы. Сформировались основные типы местообитаний, т.е. первичная геохолида. Следующий этап - первичных организмов, объединенных в первичные группировки, сообщества. Сложно сказать, что это были за организмы, однако они уже выполняли определенные биогеохимические функции, в частности, были связаны с биогенной трансформацией серы. Следующий этап это период господства прокариотной жизни, «прокариотий», в течение которого за 2 млрд лет до наших дней «полностью формируется биогеохимическая машина планеты» (с. 320). Когда в атмосфере накоплено достаточно биогенного кислорода, «на протокариотную систему накладываются эукариоты», к периоду около 1 млрд лет назад сформировался новый этап - «протистий». Эукариоты, протисты становятся господствующими продуцентами. Далее появление многоклеточности ознаменовало переход к новому этапу - «метазою». Ценотические системы усложняются с появлением в них активных фаготрофов, что приводит к «гонке размеров» хищников и жертв. Крупные метазоа становятся биогенным биотопом для прокариот, начинают формироваться сложные симбиотические связи. Появлением скелетных организмов в кембрии и выходом фотосинтезирующих растений на сушу заканчивается «крупноблочная» эволюция биосферы.

В.И. Вернадский, не рассматривая специально этапы развития биосферы, не отрицая биологической эволюции, полагал, что «биосфера - это устойчивая динамическая система, равновесие, установившееся в основных своих чертах с самого своего начала...» (20126, с. 326). Однако, принимая или гипотезу панспермии, как фактически это делал В.И. Вернадский, или гипотезу абиогенеза, следует признать, что жизнь изначально существовала в достаточно простых формах и имела достаточно локальное распространение, поскольку как для появления, так и для первых шагов жизни необходимы были определенные условия. В связи с этим вызывает интерес гипотеза эмбриосферы, под которой понимается «система, физико-химические процессы в которой создали среду, где стало возможным зарождение и существование предбиологических структур, а впоследствии - жизни» (Левченко, 2012, с. 123).

Хотя невозможно делать сколько-нибудь достоверные предположения о первичных экосистемах, вероятно, что они обладали минимальной сложностью. В частности, они вполне могли быть лишены продукционного блока (Лекявичус, 2003), получая извне абиогенное органическое вещество. Дальнейшее развитие экосистем происходило по пути усложнения циклических процессов трансформации вещества.

Одним из отражений принципа «экологического актуализма» являются широко принимаемые положения о том, что всегда существовала одна схема уровней организации: популяции состояли из особей, сообщества из популяций. При этом, рассматривая самые общие признаки структуры современных экосистем, мы признаем, что при всем их колоссальном многообразии количество их общих «конструкций» довольно ограничено. Но в том, что так было всегда, заставляет усомниться гипотеза Р. Маргалефа (2011), который предположил, что первичные живые системы, скорее, были подобны сообществам и микроэкосистемам, обладая определенной 
структурно-функциональной индивидуальностью. Только так могли существовать самые ранние проявления жизни, по его мнению, адаптируясь к весьма разнообразным локальным условиям.

Однако очевидно, что это не могло обеспечить необходимого для дальнейшей эволюции давления жизни. Такая первичная биосфера обладала высокой степенью «дурного разнообразия» (Протасов, 2008). Дальнейшая эволюция этих микроэкосистем в организмы строилась на способности «тиражирования» - размножения себе подобных.

К закономерностям эволюции биосферы самого общего характера можно отнести несколько положений. Так, есть основания считать, что в ходе эволюции роль жесткого отбора определенным образом снижалась. Само усложнение форм жизни и отношений между ними приводило к снижению конкуренции и возрастанию роли кооперации: «Общим для всех эволюционных тенденций было то, что конкуренция, «борьба» между организмами отчасти уступала место кооперативным отношениям» (Лекявичус, 1986, с. 215). Важна высказанная здесь идея «эволюции эволюции». Эволюционный процесс обладает свойством неоднородности, он диверсифицирован как в эволюционном пространстве структурнофункциональных систем, так и во времени.

В силу многоплановости самого процесса эволюции биосферы различны и подходы к познанию этих процессов (Гиляров, 2007; Заварзин, 2001, 2003, 2007, 2007а; Кордюм, 1982; Красилов, 1986, 1992; Левченко, 1992, 2010, 2012; Лекявичус, 2003; Пономаренко, 2007; Северцов, 1997; Lapenis, 2002; Пучковский, 2013; Krassilov, 2014), тем не менее можно сформулировать несколько общих принципов:

- Биосфера есть биокосная система, поэтому, взаимодействуя, косные и живые элементы системы развиваются как в единстве, так и по своим собственным законам. Эволюцию биосферы как целостной системы нельзя свести к сумме преобразований её элементов.

- Более сложные системы (с большим количеством элементов и связей) могли образоваться только из более простых, которые существовали ранее более сложных.

- Поддержание функционирования более сложных систем требует больших затрат энергии, чем это необходимо для более простых. Количество поступающей извне энергии и эффективность её использования может лимитировать уровень сложности экосистем и биосферы в целом на том или ином этапе эволюции.

- Достаточно продолжительные экологические процессы могут существовать только на основе циклического обмена веществом между биотическими системами и средой за счет трансформации энергии. Важнейшим элементом эволюции биосферы является развитие и усложнение циклических процессов обмена вещества и способов трансформации энергии.

- Отношения между биотическими элементами экосистем строятся как на принципах конкуренции, отбора, так и на принципах симбиоза, кооперации и взаимопомощи. В процессе эволюции симбиотические отношения приобретали все более важную роль эволюционного фактора. Отбору подлежат не только элементы, но и целостные симбиотические системы.

- Биокосные открытые системы развиваются с определенной направленностью, а именно в сторону снижения энтропии. 
- Антиэнтропийные процессы требуют определенных затрат энергии, поэтому развитие систем может идти неравномерно - до достижения определенного уровня организованности на изменяющейся только в деталях структурной базе и определенном способе получения и трансформации энергии, а затем относительно быстрой перестройке и создании структур с новыми элементами, позволяющими более эффективно использовать материальные ресурсы и энергию.

- В эволюции биосферы имеют место процессы переменного в геологическом масштабе времени характера. Бурные перестройки, периоды существенного снижения слаженности, когерентности процессов следуют за кризисными периодами.

- В эволюции биосферы широко распространены процессы аддитивности, накопления, сосуществования старого и нового.

Эволюционный процесс неоднороден по самой своей природе. В частности, с этим связан принцип смещения эволюции, предложенный на основе анализа эволюции человека В.А. Красиловым (1986). Он приходит к заключению, что имело место важное эволюционное явление: эволюция человека практически полностью сместилась из области морфологии в область социальности и культуры. Гетеробатмия, т.е. совместное обитание древнейших и позже появившихся таксонов (Тaхтаджян, 1998), тоже основана на принципе смещения эволюции: виды, так называемые живые ископаемые, не «останавливаются» в своем развитии, но переходят в иную область эволюции, происходит смещение в трендах их развития. Например, цианобактерии, морфологически мало изменившись за сотни миллионов лет, эволюционировали, успешно приспособившись к существенным изменениям условий жизни, колоссальному ряду экосистем, которые сменились за этот период.

Гетеробатмия выступает, по словам А.М. Гилярова (2007), характерной особенностью биосферы, результатом её эволюции, которая происходит по принципу аддитивности, накопления, добавления новых компонентов к существовавшим ранее. Таким образом, ни один из компонентов этой развивающейся системы, будь он «новым» или «старым», не может не изменяться если не морфологически, то по другим характеристикам. Эволюция их не останавливается.

Принцип естественного отбора признан одним из основных как в классическом дарвинизме, так и в более поздних его модификациях (Грант, 1991; Lashin, Suslov, Matushkin, 2012; Пучковский, 2013). Однако речь идет, как правило, об отборе на уровне популяций и видов. Но отбор - явление универсальное. Он представляет собой всеобщий механизм (или инструмент, если отбор осуществляется направленно человеком) в развитии систем.

Отбор - это фактор автоматической регуляции развития системы. Если отбор и имеет созидательную функцию («творческий отбор» И.И. Шмальгаузена (1968)), оборотная сторона его всегда разрушительная - элиминирование «менее приспособленных», «устаревших» систем. Но в этой связи важно замечание Г.А. Заварзина: «По-видимому, дело не в отборе, а в подборе системой необходимого для её существования элемента, которым служит подбираемый объект. Подбор осуществляется по необходимой функции» (2007a, с. 338). Исходя из этого, отчетливо видна определяющая роль системы более высокого уровня. Биосфера на том или ином этапе своего существования «подбирает» соответствующие биогеомы, которые, в свою 
очередь, соответствующие экосистемы. При этом совершенно справедливы слова В.В. Жерихина: «...отбор вообще не происходит ни по какому признаку, кроме числа потомков, достигнувиих репродуктивного возраста $u$ в свою очередь успешно размножившихся» (2003, с. 462). Однако очевидно, что это замечание касается только одного - организменного - уровня.

В главе 4 «Происхождения видов» Ч. Дарвин даёт следующее определение отбора: «Сохранение полезных индивидуальных различий или изменений и уничтожение вредных я называю естественным отбором, или переживанием наиболее приспособленных» (1907, c. 118). Изначально в теории Дарвина отбор это выбор из множества вариантов, неважно как он делается - человеком или естественными факторами, конкурентными отношениями или при симбиозе. В таком случае наиболее важным в концепции отбора есть не столько сам выбор, сколько наличие мультвариантности (у Дарвина это изменчивость вида, но в других системах эта множественность может иметь иной характер).

Суть дарвиновской концепции отбора, как верно отмечал Н. Винер (1958), в том, что «флора и фауна на Земле состоит из форм, которые дошли до нас просто как остаточные формы, а не вследствие какого-нибудь прямого процесса стремления к совершенству» (с. 206). Однако очевидно, что указанные современные флора и фауна не смогли бы существовать, если бы вся среда обитания (для каждой экосистемы среда - это соседние экосистемы) не изменялась бы, не эволюционировала вместе с живыми организмами. Биосфера и её элементы эволюционируют как целостные системы.

Для действенного отбора необходимо выполнение условий когерентности в системе. Выбор нового содержания не может быть успешным, если отсутствует необходимая форма, структура. Отбор новой функции должен обеспечиваться новой соответствующей структурой. Запущенный механизм не может «отказаться» от выбора вариантов, если они появляются.

Если использовать параллели из техники или архитектуры, то ни один новаторский проект не может быть воплощен в жизнь при отсутствии когерентного развития всех трендов - совершенствования материалов, инженерных расчетов, развития функциональных социальных потребностей, способов и источников использования энергии и т.д. Отбору подвергаются как элементы системы, так и система в целом.

Так же и в эволюции биосферы: для эволюционных изменений всей системы необходимы слаженные когерентные изменения во многих эволюционных трендах.

Как полагает В.С. Пучковский (2013), конкурирующие системы, которые являются единицами отбора, могут быть представлены различными уровнями - от особей до зональных биомов в составе биосферы. Отбор, по его мнению, - это редукция одного из двух конкурентов. Однако очевидно, что отбору подлежат как целостные системы (отбор одного из двух конкурирующих организмов, популяций), так и отдельные элементы систем. Если в сообществе А возникают новые популяции, то отбор либо отсекает их и сообщество продолжает оставаться «самим собой», либо не отсекает, сохраняет и сообщество трансформируется в сообщество Б.

Если пользоваться принципами передачи информации, то информация о структуре сообщества в состоянии А передается с «ошибками», информационным шумом, поскольку имеет место наличие новых популяций, структура выглядит иначе, отбор может «отфильтровать» эти шумы, но может и про- 
пустить. В том смысле, что сообщество в состоянии Б окажется вполне жизнеспособным в условиях новых относительно таковых для сообщества А.

\section{Кризисы в эволюции}

\section{и революционные перестройки. Пульсирующая эволюция}

Рассматривать кризисные состояния биосферы как промежуточные между периодами когерентной, «устойчивой» эволюции (Красилов, 1986) вряд ли корректно. Кризисные периоды, о которых писал В.А. Красилов, это скорее достаточно быстрые революционные перестройки. Здесь можно провести параллели со сменой экоморфных состояний в онтогенезе: интерэкоморфные стадии никогда не бывают длительными (Алеев, 1986).

Что касается сложности и многообразия возникновения кризисных явлений, то при всей важности внешних факторов, включая и космические (Красилов, 1992; Левченко, 2012), в основе их лежат внутренние для систем процессы. Внешние воздействия в худшем случае могут разрушить систему. Но это сугубо эндогенный процесс. Один из механизмов взаимодействия разнообразия среды и биокосных систем основан на одном из постулатов диверсиологии, принадлежащем У. Эшби (Ashby, 1957): разнообразие управляющей системы не может быть меньше, чем управляемой. Многообразию негативного воздействия среды сообщество должно противопоставлять разнообразие механизмов сопротивления дестабилизации. Так же и для максимального использования ресурсов должна существовать определённая многообразная система их потребителей. При этом важно отметить, что при росте разнообразия воздействий должны возрастать затраты энергии сообщества на поддержание высокой организации и собственного разнообразия.
Кризис - это состояние разрушения когерентности, но оно не обязательно должно быть причиной последующей революции, может быть причиной прямого разрушения системы. Только в том случае, когда кризис готовит революционную смену состояния, можно говорить об эволюционном процессе. Без периодических революций нет эволюции. Революция по сути - это триггер, переключатель эволюционного процесса.

Причины и предпосылки кризисов многообразны. Так, В.В. Жерихин полагает, что «все способы регуляции эволюции вероятностны и не абсолютно надежны» (1986, с. 12). Из этого следует, что даже если нет разрушительных факторов среды, «сообщество все равно будет рано или поздно разрушено вследствие эволюции своих компонентов, несмотря на совершенство механизмов, репрессирующих эту эволюцию» (с. 12). Еще одну причину кризисных явлений можно связать с «давлением эволюции», которое можно рассматривать как одно из проявлений давления жизни, о котором много писал В.И. Вернадский (2012). Сама идея восходит к Ч. Дарвину и Т. Мальтусу. Давление жизни - это не только потенциальный рост численности организмов, но и возникновение все новых форм, новых связей в экосистемах, что может вызывать определенные экологические напряжения и кризисные ситуации. Как считает В.С. Пучковский (2013), именно давление жизни, а не отбор служит важнейшим фактором эволюции. Представляется, что, скорее, это два неразрывно действующих фактора.

Когерентные периоды - отнюдь не застой и отсутствие развития. Происходит формообразование, все большая специализация, все более плотная «упаковка» экологических ниш в сообществах, возрастание общей сложности экологических систем. Это и определяет то, что мы называем давлением эволюции. 
Образно говоря, новым формам становится все более тесно в старой системе.

Кризис может заключаться в том, что существующие механизмы получения и трансформации энергии уже не могут поддерживать существующую и все более усложняющуюся систему организации и накопившейся информации. Именно на энергетические предпосылки кризисных явлений в биосфере указывает и В.Ф. Левченко (2012).

Если обратиться к историко-социальным аналогиям, то ни одна процветающая и благополучная цивилизация, империя не процветала бесконечно долго. Система не может не только существовать в вечной неизменности, но и развиваться долго в одном направлении, наблюдается нечто вроде усталости системы. Развивающаяся система не может бесконечно долго использовать одни и те же ресурсы и неизменные источники энергии, а также способы её трансформации.

При онтогенезе, развитии системы любого организма происходят постоянные репарационные, регулирующие процессы, тем не менее накапливается груз таких изменений, справиться с которыми система уже не может, наступает старение и смерть. Не исключено, что за счет тех или иных механизмов, требующих, однако, все больших затрат энергии, система организма может продлить срок своего существования. Но необходимо ли это популяции? В популяции должна происходить смена поколений. Нужны ли «вечноклимаксные» сообщества и «бессмертные» экосистемы биосфере? Отрицательный ответ на этот вопрос имеет два важных следствия. Во-первых, любая система не может бесконечно эволюционировать и совершенствоваться на одной структурной основе, затрачивая на поддержание все более сложной, но принципиально в своей основе неизменной структуры все больше и больше энергии; во-вторых, регуляция в биосфере может идти преимущественно по принципу сверху вниз. Таким образом, кризисные явления представляются неизбежным условием эволюционного процесса биосферы. Эволюция приобретает не поступательный, а скорее пульсирующий характер.

Однако существующие палеонтологические данные при разных концептуальных подходах приводят к разным и довольно противоречивым выводам. В частности, это проявляется в двух моделях изменения таксономического богатства в фанерозое.

Первая (Марков, Коротаев, 2008) описывает «бескризисный» непрерывный рост, причем гиперболического характера, с возрастанием результирующей от появления новых таксонов и вымирания. Увеличение количества таксонов, исходя из экологической логики, должно быть обусловлено возрастанием ёмкости среды, более плотной упаковкой ниш, снижением конкуренции, а также возрастанием кооперативных или симбиотических связей. Поэтому интегрированная кривая роста таксономического богатства, которая описывается как гиперболический рост, определенно свидетельствует о неуклонном росте сложности организации всей биосферы, сложности внутри- и межэкосистемных связей.

Другая модель (Sepkosky, 1992, цит. по: Global Biodiversity, 1995) представляет собой систему взаимодействующих, довольно обособленных биот разных геологических эпох, которые своими периодами существования определяют границы крупных эволюционных периодов. В модели выделяются достаточно стабильные зоны, когда существовали кембрийская, палеозойская, мезозойская и кайнозойская биоты. Разделяют их относительно краткие периоды вымираний и перестроек биот. Вся картина в этой модели выглядит как 


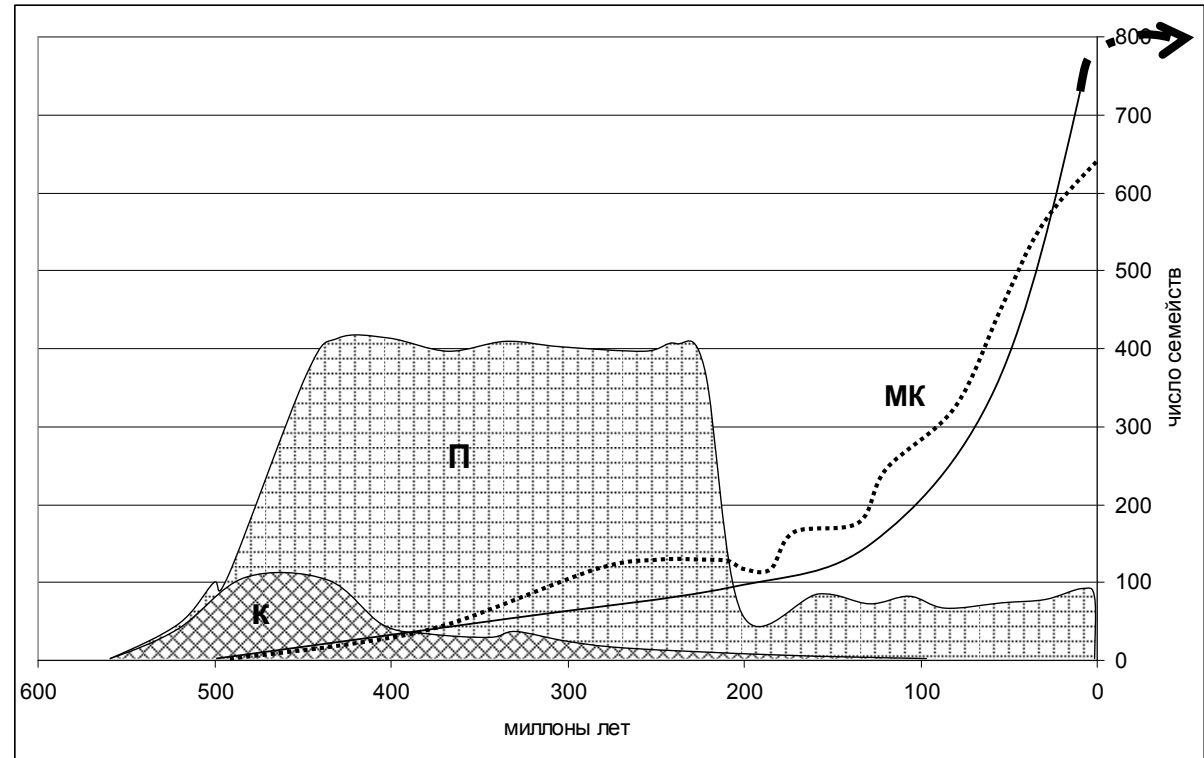

Рис. 2. Изменение богатства семейств морских животных в фанерозое (по Sepkoski, 1992, из Global..., 1995). К - кембрийская биота, П - палеозойская, МК (точечная линия) - мезозойско-кайнозойская и современная. Сплошная линия - гиперболический рост богатства морской фауны (по Марков, Коротаев, 2008), стрелка с пунктиром - гипотетическое изменение богатства

периодически кризисная или пульсирующая эволюция (рис. 2).

Вторая модель представляется более реальной, отвечающей существовавшей периодичности процессов, подтверждаемых палеонтологическими данными. Однако следует обратить внимание на такую деталь. Каждый начальный период становления биоты подобен резко возрастающему участку экспоненциальной кривой в первой модели. Тогда можно выдвинуть такую гипотезу: возможно, первая модель отражает только часть более масштабного эволюционного процесса и биосфера в настоящее время находится на своем подходе к когерентному «мегаплато». Таким образом, и в первой модели революционные перестройки оказываются, вероятно, неизбежными в будущем. Следует отметить, что авторы первой модели также задумываются о том, что кривая роста таксономического богатства не может «уходить в бесконечность». .

\section{Механизмы и модели эволюции биосферы}

Если количество различных теорий биологической эволюции исчисляется десятками (Lashin, Suslov, Matushkin, 2012), то моделей эволюции биосферы существует гораздо меньше. Зачастую как эволюция биосферы рассматривается только эволюция биотических систем (Колчинский, 1990). Остановимся на некоторых подходах и обобщениях, касающихся эволюции биосферы.

Модель прямого усложнения биосферы «снизу вверх». Биотическая эволюция происходит с увеличением количества таксонов, сообщества и экосистемы становятся богаче, за ними в целом усложняется биосфера. Обмен наследственной информацией имеет панбиосферный характер (Кордюм, 1982), существует единый генопласт сообществ и экосистем (Голубец, 1983). Отбор постоянно отсортировывает «лучшие образцы», предлагаемые случайными мутациями, дрейфом 
генов, обменом генетическим материалом за счет вирусов и т.П. В качестве эволюционирующей единицы рассматривается «вся биосфера в целом» (Кордюм, 1982), однако под ней подразумевается биохолида. При этом живые организмы и их ассоциации активно воздействуют на среду, приводя её во все более пригодное для жизни состояние.

По мнению И.И. Шмальгаузена (1968), в эволюционном процессе перестраивается «флора и фауна - вся жизнь как в воздушной, так и в водной среде, как на суше - материках и островах, так и в морях и океанах» (очевидно, имеется в виду вся биосфера), однако в основе этих преобразований лежит «эволюция... организмов как индивидуальных представителей видов» (с. 178). То есть эволюция многоуровневой иерархической системы сводится к изменениям лишь одного уровня. Таким образом, эволюция биосферы как макросистемы обусловлена развитием одного из её элементов.

Однако структура биосферы основана на биокосных экосистемах. Эволюция биосферы - это необратимая смена все усложняющихся экосистем и их типов, а не только изменение состава живых организмов. Можно считать, что (пользуясь терминологией Г.А. Заварзина (2007) «вмещаемое» эволюционирует вместе с «вмещающим» как единая система.

Другая модель основана на функциональном подходе, развитии экосистемного метаболизма (Лекявичус, 2003). В биотической части экосистем происходит постоянный спонтанный процесс формообразования, возникают новые виды и формы, что влечет за собой появление новых вариантов функциональных взаимосвязей, которые, в свою очередь, создают новые ресурсы и новые «ниши». Эволюция биосферы рассматривается как эволюция типов экосистем. Посколь- ку новые формы присутствуют в некотором избытке (их поставляет эволюционный процесс на уровне видов, форм), то всегда есть возможность освоения появляющихся неиспользуемых ранее ресурсов, новых вариантов взаимодействий. Отбор работает на заполнение появляющихся «ниш». Возрастает как количество различных экосистем, так и их сложность. Не только в смысле усложнения таксономической структуры, богатства, но и усложнения структуры трофических уровней, биоценотических взаимосвязей. Автор использует принцип «экосистемного актуализма», утверждая, что «те же силы, которые управляют сегодняшней работой экосистемы, направляли её эволюцию на протяжении миллионов лет» (с. 374). Важно то, что формируются все более сложные циклические процессы образования и трансформации органического вещества. В основе эволюции экосистем, согласно этой модели, лежат взаимосвязанные процессы образования новых ресурсов, эволюция утилизаторов этого ресурса. В этой модели принципиально отсутствует необходимость во внешних внебиосферных управляющих или пусковых факторах.

Еще одна модель (Красилов, 1986, 1992) базируется на двух принципах - когерентности эволюционных процессов и запуске смен когерентной и некогерентной эволюции внешними факторами. Когерентная фаза характеризуется состоянием сообществ, близким к климаксу, - высоким разнообразием, плотной упаковкой ниш, весьма узкой специализацией относительно используемых ресурсов. Внешние факторы, в том числе космические, служат причиной смещений в уравновешенных системах, нарушений связей со средой. Процессы теряют необходимое важное свойство когерентности. В периоды некогерентного развития биосферы происхо- 
дят глобальные перестройки в экосистемах, экологическое преимущество получают не прежние доминанты, а быстро размножающиеся, неспециализированные формы. За относительно короткий период геологического времени в биосфере формируются иные, чем существовавшие ранее, экосистемы, вследствие чего она меняет свою структуру и облик.

Предполагает существенную роль тех или иных внешних факторов в эволюции биосферы и физико-экологическая модель (Левченко, 2012). В основе этой модели лежит так называемая панбиосферная парадигма, которая, в частности, постулирует, что биологическая эволюция должна рассматриваться как компонент, один из элементов панбиосферного процесса, направленного на сохранение жизни на планете. Каждый из анализируемых моментов жизни биосферы представляет собой состояние, подготовленное, обусловленное предыдущими. Важным определяющим моментом выступает физическая эволюция всей биосферы, которая связана с энергетическими процессами.

\section{Информационная концепция эволюционных процессов}

\section{Шмальгаузена - Винера - Маргалефа}

Кибернетическая информационная модель эволюционного процесса, разработанная И.И. Шмальгаузеном (1968а), затрагивает только самые нижние иерархические уровни организации биосферы - популяционный и экосистемный. Суть её состоит в том, что популяции передают информацию о своем состоянии экосистеме, которая, в свою очередь, является управляющей системой для популяций. Насколько эта информационная модель универсальна и может быть применена для последующих уровней организации биосферы и что собой представляет информация? Н. Винер указывал, что «за единицу её количества принимается количество информации, передаваемое при одном выборе между равновероятными альтернативами» (Винер, 1958, с. 55). Введение в экологию информационных представлений и способа измерения информации связывают с именами Р. МакАртура и Р. Маргалефа, однако, по мнению А.Ф. Алимова и соавторов (2013), именно И.И. Шмальгаузеном было предложено в биологии соединение понятий «разнообразие» и «информация». Благодаря этим ученым в различные разделы экологии вошла функция, определяющая разнообразие, сложность, степень упорядоченности сообщества $\mathrm{H}=-\Sigma \mathrm{p}_{\mathrm{i}} \cdot \log _{2} \mathrm{p}_{\mathrm{i}}$, где $\mathrm{p}_{\mathrm{i}}-$ вероятности для і-го элемента данной системы. В современных исследованиях этот показатель структуры сообществ рассматривают как степень их сложности (Алимов и др., 2013).

Как отмечал И.И. Шмальгаузен, «теория информации дает возможность учесть состояние популяции в числовом выражении» (1968a, с. 57), так же можно учесть и состояние сообщества, экосистемы и вообще той или иной системы. Определение среднего количества информации, содержащейся в структуре сообщества, он параллельно с американским экологом Р. МакАртуром предложил рассчитывать с помощью энтропийной статистической функции. Информация той или иной системы заключена в её структуре, а именно в количестве, богатстве элементов и выравненности или относительной их представленности.

Учитывая неформальное сходство информации и энтропии, вслед за Ю. Одумом отметим, что важнейшей термодинамической характеристикой живых (организмов, сообществ) и биокосных (экосистем и биосферы в целом) является «способность созда- 
вать и поддерживать состояние внутренней упорядоченности, то есть состояние низкой энтропии» (Одум, 1975, с. 52).

Генетическая информация передается особи и перекодируется в фенотипическую информацию (Шмальгаузен, 1968а), а информация, заключенная в структуре популяции, передается биогеоценозу, который, в свою очередь, связан обратными информационными потоками как с популяцией (управление top-down, сверху вниз), так и с системой иерархически в биосфере более высокого уровня. Таким может быть управление не только гомеостатирующими функциями, но и эволюционными процессами, в который включается отбор.

Bce живые и биокосные системы подвержены отбору различными факторами. Особи подвержены отбору более высоким уровнем - популяцией. Последние подвержены отбору экосистемой, в свою очередь, подверженной отбору биогеомом. Биосфера контролирует отбор в биогеомах. Каждый из более низких уровней передает информацию о своей структуре более высокому уровню. И эта передача информации не может происходить абсолютно идентично, всегда присутствует определенный шум, ошибки. Эти ошибки и создают необходимое разнообразие вариантов для отбора (изменчивость, мутации, новые популяции и т.п.). Отбору подлежат не только и даже не столько целостные системы, но и элементы систем. Здесь нет противоречия с классическим понятием отбора (см. выше цитату из (Жерихин, 2003), поскольку организмы, индивиды, «неделимые» - это системы, существенно отличные от популяций или экосистем. Процесс фотосинтеза когда-то был явной «ошибкой» относительно архейских обитателей биосферы. Новая информация рождается из «шума» (Пучковский, 2013).

\section{Информационные каналы и эволюционные тренды}

То или иное состояние системы любого уровня является следствием передачи информации от предыдущего и передает новую информацию последующему. Состояния развивающихся систем связаны в единую систему (онтогенеза, сукцессии, эволюции) характерными для систем трендами. Существование трендов, воспринимаемое на интуитивном уровне, довольно сложно поддается формализации и объяснению в биологических терминах. Р. Маргалеф (2011) выделяет для экосистемы три информационных канала: генетический, экологический, этологический или культурно-социальный. Важно то, что он связывал функционирование этих каналов с развитием, эволюцией, вводя в общую систему время. Экологический канал можно рассматривать как первичный (первичные живые системы, согласно его представлениям, были скорее примитивными экосистемами, нежели организмами), но этот канал становится впоследствии и весьма консервативным, поскольку принципиальные структуры организации сообществ и экосистем сложились на довольно ранних этапах эволюции биосферы. Он приводит следующий пример: «...на экологическом уровне современные леса передают не намного больие информации, чем мезозойские» (с. 90), другими словами, состав сообществ иной, но организация экосистем довольно сходна. Тем не менее на вполне очевидные закономерные изменения структур указывал Э. Лекявичус (2003), рассматривая эволюцию сообществ и экосистем. Генетический информационный канал появился как реализация возможности дупликации, «тиражирования» живых систем, которые и стали тогда собственно организмами. «Дарвиновская» эволюция видов привела к существенному расширению этого канала в 
эволюционном времени. Наконец, этологический канал появился с возникновением достаточно высокоорганизованных организмов и их ассоциаций, в которых проявились новая информация, например, на основе обучения, формирования социальных отношений, передача информации новым поколениям стала возможна, минуя наследственный генетический информационный канал. Взрывообразный характер этот тренд приобрел с появлением человека. К совершенно аналогичным построениям относительно биологической основы культурного тренда приходит В.А. Красилов (1986).

Информационных каналов, эволюционных трендов, очевидно, гораздо больше трех, выделенных Р. Маргалефом. Однако количество их в принципе должно быть конечным, поскольку передача информации требует определенных энергетических затрат, которые, очевидно, должны возрастать в процессе эволюции (вероятно, одной из важнейших функций эволюционирующей системы биосферы есть это обеспечение все возрастающих затрат энергии на передачу информации).

Представляется, что, принимая идею Маргалефа, можно рассматривать эволюционные тренды как информационные каналы, посредством которых информация, дифференцированная по отдельным направлениям, передается между предыдущими и последующими состояниями материальной системы биосферы. Он ставит очень интересную, важную, но крайне сложную задачу, формулируя её в рамках вопроса: «...как общая информация, переданная в биосфере к настоящему времени, распределялась по этим трем каналам?» (2011, с. 90).

В первую очередь в соответствии со структурно-функциональной организацией биосферы эволюция геохолиды и биохолиды должна протекать как взаимосвязанно, так и независимо. В группе абиотических трендов следует выделить тренды эволюции литосферы, гидросферы, атмосферы, т.е. тех косных элементов биосферы, которые создают биотопы как элементы экосистем или единый косный «каркас» живой части биосферы. Единый Мировой океан, периодическое единство материков, а при их разъединении - существование крупных континентов, единая система движения воздушных масс в атмосфере - все это было важнейшей предпосылкой формирования единой структуры биосферы.

\section{Система биотических трендов выглядит} более сложной. Наиболее «популярен» в эволюционных исследованиях тренд генетический, или таксономический. Многими, если не большинством исследователей, эволюция биосферы рассматривается только или в первую очередь как эволюция живых организмов, более или менее в русле дарвиновского учения о происхождении видов, даже если речь идет об эволюции всего живого, биохолиды (Колчинский, 1990). По сути, это тренд генетической эволюции. Количество генетически различных таксонов огромно, даже на отдельных территориях или акваториях (Kolmakova et al., 2014). При этом довольно ограничено количество экологических и биосферных функций, которые выполняют организмы, т.е. существует их определенная функциональная избыточность.

Для эволюционной системы в целом важны не столько механизмы видообразования и филогенеза, сколько то, что таксономическое богатство в процессе эволюции возрастало, как росло и разнообразие в этом тренде, поскольку ни один вид не играл исключительной, подавляющей роли.

Однако реально организм существует в природе не только в виде носителя генетической информации, принадлежит не только к определенному виду, но существует в виде 
конкретной реальной экоморфы, жизненной формы, которая определяется как историческими наследственными связями, так и условиями жизни организма (Алеев, 1986). Исходя из этого одним из важных эволюционных трендов признан тренд экоморфный. В нем прослеживается вполне закономерная смена экоморф и жизненных форм организмов, появление и закрепление целых типов экоморф. Экоморфный тренд - один из наиболее важных в процессах конвергентного развития.

Эволюционное учение Ч. Дарвина и последующее его развитие в основе механизма эволюционных преобразований ставят отбор, отношения конкурентного типа (Дарвин, 1907). Однако в природе сильны кооперативные симбиотические отношения в самом широком смысле. Они не только были важны в чисто биотических системах, но также изменяли и отношения живого с косной средой. Поэтому симбиотический тренд также может рассматриваться как один из важнейших в эволюции биосферы. Двумя, вероятно, самыми значительными явлениями в этом тренде было возникновение эукариотной клетки на основе симбиоза прокариот, а также формирование симбиотических систем между метазоа и одноклеточными организмами. В современной биосфере вообще вряд ли можно найти организмы, которые существуют вне симбиотических связей, что позволило выдвинуть концепцию аутоценоза (Савинов, 2012). Организм с его симбионтами рассматривается как «холобионт» с объединенным геномом, который, собственно, и включается в эволюционный процесс (Rosenberg, Zilbert-Rosenberg, 2009).

Биохимический эволюционный тренд это история процессов формирования нового биологического «материала» для построения организмов, а также новых, все более сложных биохимических процессов. К тому же каждая из девяти биогеохимических функций биосферы (Вернадский, 2012а) поддерживается определенными биохимическими механизмами в живых организмах. Этот тренд связывает эволюцию гео- и биохолиды, поскольку биохимические процессы могли возникнуть только на основе геохимических, те и другие в биосфере тесно взаимосвязаны.

Тренд разнообразия. Возникновение и возрастание биологического разнообразия рассматривается как основной путь эволюции экосистем и биосферы в целом. Разнообразие имеет две компоненты - богатство элементов той или иной системы и выравненность, т.е. относительную представленность в системе элементов (Маргалеф, 2011). Очевидно, что разнообразие может быть не только «видовым», поскольку рассматривается в соответствии со структурой изучаемой системы.

Таксономическое богатство как один из компонентов разнообразия биосферы возрастало в эволюционном времени со все большей скоростью, во всяком случае, за период фанерозоя (Марков, Коротаев, 2008). Что касается выравненности, то здесь сложно проводить оценки, тем не менее можно полагать, что ни один из таксонов, трофических групп не занимал подавляюще доминирующего положения. Таким образом, общее разнообразие биосферы, видовое, таксономическое, экоморфное, трофическое и др., в процессе эволюции возрастало. Тезис Г.А. Заварзина (1995) о том, что возникновение разнообразия есть антиконкурентный способ выживания, созвучно дарвиновскому: «...чем более органические существа различаются по строению, внутреннему складу и привычкам, тем большее их число может существовать на данной площади» (Дарвин, 1907, с. 153). Таким образом, разнообразие свойств организмов обусловливает богатство сообществ и экосистем.

Выделение тренда эволюции экосистем биосферы очевидно, поскольку именно экоси- 
стемы представляют собой единицы её структуры. Эволюцией экосистем было постепенное изменение в них круговоротов вещества, состава и структуры биотических сообществ, интегрирующих параметров локальных экосистем, объединение их в иерархические системы вплоть до биосферы (Лекявичус, 2003). К этому следует добавить изменение способов получения и трансформации энергии. При огромном количестве локальных экосистем число сходных их типов - биогеомов - было небольшим.

Тренд эволюции биогеомов прослеживается, на наш взгляд, достаточно определенно. В современной биосфере можно выделить более десяти биогеомов (Протасов, 2012). Эволюционный возраст их различен, экосистемы биогеомов за период эволюции существенно изменялись по составу, однако сохраняли свои ключевые характеристики. Например, биогермовый биогеом с древнейших времен был представлен строматолитовыми постройками, в различные периоды фанерозоя - мшаночными, рудистовыми, коралловыми рифовыми экосистемами. Наиболее молодыми современными биогеомами являются, вероятно, биогеом гилеи и тундровый (Разумовский, 1999).

\section{Эволюционная система}

\section{биосферы}

Сходство онтогенетической системы, системы экологической сукцессии с эволюционной системой биосферы состоит в том, что квазистатические состояния в них связаны определенными информационными трендами. Информация о структуре систем передается в определенном канале, тренде, связанном с тем или иным аспектом структуры. В экосистемах и биосфере в целом происходят изменения во многих аспектах, определяемых системой трендов: в таксономическом и экоморфном составе, составе жизненных форм, способах получения и трансформации энергии, круговоротов вещества, антиэнтропийных процессах, в косных элементах геохолиды. Тренды определяют некоторые области общей направленности развития систем. Каждое последующее состояние базируется на предшествующем, но сможет или нет оно существовать в настоящем, зависит от многих, в том числе и случайных, факторов.

Иерархическая структура биосферы определяет существование системы прямых и обратных связей между структурными уровнями. Собственно, эти связи и поддерживают иерархическую структуру. В процессе взаимодействия этих связей осуществляется отбор. Он работает как по принципу редукции сложности системы - элиминации одних и выживания других целостных систем как единиц, так и путем «фильтрации» ошибок при передачи информации о структуре систем от прошлого состояния к текущему/настоящему, а от него к будущему.

При постоянном давлении биологической эволюции - возникновении новых таксонов, новых форм - происходят процессы самоорганизации систем вследствие антиэнтропийной деятельности биокосных систем, возрастания когерентности. Однако нарастают и негативные процессы, вызванные «усталостью» систем, накоплением нарушений, развитием кризисных явлений. Растет богатство таксонов при ограниченности ресурсов, это усиливает конкурентные отношения, сложившиеся системы использования ресурсов и способы трансформации энергии уже не могут удовлетворить потребности систем. Эти процессы имеют свойство пространственной, хорологической когерентности в масштабах биогеомов, всей биосферы, охватывают большие её области. Часть биокосных систем, целые биогеомы могут деградировать и исче- 
зать с Земли вследствие кризисов. В других же частях биосферы кризисы разрешаются революционными преобразованиями, что сопровождается массовыми вымираниями, но и бурным формообразованием, формированием принципиально новых связей, новых крупных структур биосферы, новых биогеомов.

\section{Ноосфера и ноосферогенез}

Биоантропогенный тренд стал продолжением и развитием тренда как генетического, так и этологического, социального (Маргалеф, 2011; Красилов, 1986). Этот тренд существует с начала эволюционного периода появления на Земле прямых биологических предков человека. Но, как отмечал В.А. Красилов (1986), в течение последних 30-40 тыс. лет человек как биологический вид находится в состоянии морфологического стазиса: «...человек в эволючионном смысле уникален, так как его эволючия почти полностью смещена в область культуры» (с. 81). Таким образом, биоантропогенный тренд трансформировался в антропосоциокультурный, развитие человеческого социума и культуры есть продолжение эволюционного биологического тренда. Человек является поистине уникальным видом по своему воздействию на другие популяции и экосистемы, однако он остается одним из многих биологических видов в биосфере. Как полагал Р. Маргалеф, «культурный, или этологический, канал стал развиваться и расти с развитием позвоночных, a с приходом человека этот рост приобрел характер взрыва» (2011, с. 92), т.е. он считал этот тренд непрерывным независимо от того, кто создавал эти социальные системы - организмы, наделенные только инстинктами, или человек, имеющий разум.

Одной из сторон функционирования антропогенных социобиокосных систем является создание не только орудий труда, соору- жений, строений и технических средств, но и создание совершенно новых типов экосистем, в которые входят антропогенные составляющие. В биосфере формируются в дополнение (или на смену) к естественным антропогенные экосистемы - агро-, урбо- и техноэкосистемы (Протасов, 2013, 2014). Лик Земли, её биосфера приобретают новые черты вследствие действия не только чисто природных факторов, но и антропогенных.

Начало учения о ноосфере связывают с именем В.И. Вернадского, но сам термин и понятие были предложены в 1927 г. французским философом Э. Леруа. Свои представления о ноосфере - новом состоянии биосферы - В.И. Вернадский изложил, в частности, в одной из своих последних работ (2012а). Вернадский указывал на изменения, именно «перестройку» биосферы, но никак не на формирование ноосферы как некоей надстройки над структурами биосферы: «... человечество в иеелом становится мошной геологической силой... перед ним становится вопрос о перестройке биосферы в интересах свободно мыслящего человечества как единого иелого. Это новое состояние и есть ноосфера» (2012a, с. 464). Важно то, что В.И. Вернадский говорил о единстве планетарных процессов. Иными словами, в единую структуру биохолиды и геохолиды постепенно входит новая структура - «ноохолида». Что может представлять собой последняя? Приведем цитату из «Новой философской энциклопедии» (www.http://iph.ras.ru/elib/2117.html): «Тейяр де Шарден считал личность минимальной структурой ноосферы, подобно тому как атом является минимальной структурой материи, а клетка - жизни. Т.о., ноосфера возникает и развивается вследствие осознанной и производимой в собственных интересах трансформации мира человеком». Очевидно, что функционально в центре этой новой системы 
находится человек, однако может ли человек, как и любой другой вид живых организмов, входить в любую - экологическую, социальную, информационную, культурную - систему вне связей со средой, окружением? Ответ очевиден: нет, не может. Сомнительна и посылка относительно современной личности как единицы зарождающейся и грядущей ноосферы, поскольку вряд ли есть основания проводить какие-либо границы между личностями древнейшего человека - автора многих культурных ценностей и фундаментальных технических достижений, которая «еще не была» единицей ноосферы, - и современными «ноосферными личностями». Личность есть форма существования человека в социуме. Однако происхождение её имеет глубокие биологические корни.

Если биосферу рассматривать как иерархическую систему, в основе которой находится биокосная экосистема, то логично полагать, что формирование «нового состояния биосферы», ноосферогенез есть трансформация части этих систем. Как бы ни было уникально в истории биосферы воздействие человека на многие её элементы, переход к ноосфере должен рассматриваться как один из многих уже повторявшихся этапов её эволюции.

Само по себе наличие разума у человека не приводит к трансформации биосферы. Реальный путь этой трансформации есть прогрессирующая замена одних её элементов другими - антропогенными, а точнее, природно-антропогенными. Результатом человеческого труда являются не столько собственно машины, механизмы, строения, заводы, электростанции, системы коммуникации и информации и т.п., сколько новые биокосные системы - антропогенные экосистемы.

Для конца первой половины XX в. в качестве наиболее ярких примеров перехода к ноосфере В.И. Вернадский (2012а) приводит такие, как производство веществ, в частности металлов, которые не существуют в природе или очень редки, создание множества искусственных химических соединений и др. Также В.И. Вернадский неоднократно упоминает катастрофические влияния войн.

Очевидно, что к началу XXI в. все эти явления в огромной мере возросли, появились новые. Они оказывают значительное, даже катастрофическое влияние на многие процессы в биосфере (Пучковский, 2013; Яблоков, Левченко, Керженцев, 2015), но коренным образом не изменяют её структуру, фундаментальные основы функционирования. Эта модель ноосферогенеза, которую можно назвать моделью постепенных преобразований, может объяснить многие изменения, но вряд ли она отражает реальную «перестройку» биосферы.

Организованность биосферы как системы - одно из ключевых её свойств (Вернадский, 2012). Сложно поверить, что «воздействие» человека, которое представляет собой в основном крайне неорганизованные, спонтанные явления, может привести к переходу из одного высокоорганизованного состояния системы в другое, не менее или еще более организованное.

Одна из моделей ноосферогенеза связана с формированием как бы параллельной системы, «какосферы» как системы-антипода или как противоположности ноосферы (Заварзин, 2003a). Этот подход довольно условно и прямолинейно разделяет многогранную связь человека и природы на две полярные области «Плохую» и «хорошую» - «экологический ад» и «экорай». Захватывая биосферу, «какосфера трансформирует географический покров планеты» (с. 630), надо понимать, не в лучшую сторону. Однако существовать биосфера может только как единая система. 
Следует отметить одну важную особенность развития социосферы в ноосфере. Постоянно присутствующее в биосфере явление гетеробатмии в человеческом обществе существенно изменяется. Если в природе более древние биотические системы выступают как вполне равноценные более молодым, т.е. нельзя говорить о каком-то разрыве, хиатусе между ними, то иначе обстоит дело в социуме. Рост технической вооруженности, результаты технического прогресса ведут не только к тем положительным и отрицательным последствиям, о которых писал еще В.И. Вернадский, но и к постоянному увеличению разрыва между бедностью и богатством, примитивностью одних биокосных антропогенных систем и сложностью, зачастую малоуправляемостью, наиболее продвинутых. Социальный парадокс технического прогресса состоит в том, что он охватывает лишь часть общества.

Предлагаемая нами модель ноосферогенеза строится на общем для всего хода эволюции биосферы явлении - эволюционной смене экосистем и их типов. Ноосферу следует рассматривать не только как новое состояние биосферы, но как новую систему, в структуру которой входят как чисто природные элементы, так и биокосные системы антропогенноприродного характера. Под ноосферогенезом следует понимать процесс формирования и внедрения в природную систему биогеоценозов нового типа биокосных систем - антропогенных, с тем или иным соотношением природных и созданных человеком элементов (Протасов, 2014). Сама по себе эта новая система ни хороша ни плоха, она новая, иная. Биокосные системы с различными антропогенными составляющими входят в новую организацию живого покрова Земли (Беклемишев, 1964).

Можно ли рассматривать ноосферу как терминальную стадию эволюционной сук- цессии? Как полагал В.И. Вернадский, «ноосфера - последнее из многих состояний эволюции биосферы в геологической истории» (2012a, с. 465). Исходя из вышеизложенных представлений об эволюции биосферы, следует ответить на поставленный вопрос отрицательно. Хотя В.И. Вернадский считал, что мы входим в ноосферу и можно смотреть в наше будущее уверенно, вхождение это сопровождается множеством явлений, которые уже неоднократно рассматривались как кризисные (Яблоков, Левченко, Керженцев, 2015 и др.). Мы, по сути, фиксируем сейчас то, что происходило в конце каждого крупного периода эволюции: кризисные процессы, нарушения когерентности, изменения экологических связей. Негативный парадокс ситуации состоит в том, что эти кризисные, крайне нежелательные для человечества явления представляются одними из «нормальных» эволюционных процессов, которые готовят революционные преобразования, вследствие которых и должно сформироваться новое состояние биосферы, на этом этапе эволюции ноосфера.

Хотелось бы выразить надежду, что уже происходящий переход от когерентной к некогерентной фазе, а затем к революционным перестройкам, как это уже было в истории биосферы, может произойти благодаря человеческому разуму не столь болезненно. В отличие от упомянутых авторов (Яблоков, Левченко, Керженцев, 2015) мы не считаем возможным реальное управление эволюцией биосферы, однако познание её закономерностей позволило бы существенно смягчить, если не устранить вероятные негативные явления.

Надежду вселяет то, что человечество пытается решать глобальные проблемы объединенными усилиями, что показала Конференция по климату в 2015 г. в Париже 
(http://unfccc.int/resource/docs/2015/cop21/eng/ 109.pdf). Хотя политическая составляющая здесь гораздо больше научно-практической. Что касается оценки повышения температуры на планете, которую связывают с выбросами так называемых парниковых газов, в первую очередь диоксида углерода, то, к сожалению, здесь отсутствует системный подход. Следует учесть, что дыхание, например, почвенных микроорганизмов на территории России в несколько раз превышает антропогенные выбросы (Заварзин, 2007). Кроме того, углерод находится в постоянном круговороте, интенсивно потребляется и выводится из оборота в карбонатных отложениях в Мировом океане, а также в мортмассе в таких экосистемах, как болотные, тундровые. Необходимо учитывать баланс углерода, а не только составляющую прихода. В этом смысле экосистемы так называемых ветлендов, достаточно сбалансированных по циклу углерода, играют гораздо большую роль, нежели экосистемы гилеи. В связи с этим положения Рамсарской конвенции (Руководство, 2006) могут иметь гораздо больше влияния на регуляции климатических изменений, нежели Киотский протокол.

Может показаться, что от проблем эволюции биосферы мы перешли совсем в другую область, которая ближе к политике, нежели к биологии, биосферологии, эволюционистике. Однако это не так. Все это одна и та же глобальная проблема: эволюция биосферы - от возникновения жизни к ноосфере и далее в неизвестное пока будущее.

\section{Заключение}

Концепция структуры и развития биосферы, представленная нами, кратко может быть сведена к следующим положениям:

- Биосфера имеет иерархическую структуру, которую образуют элементы - экосистема, региональный комплекс однотипных экосистем, биогеом, биосферомерон.

- В эволюции биосферы существуют определенные повторяющиеся периоды: высококогерентные, кризисные, низкокогерентные, революционные перестройки. Такой пульсационный режим в геологическом масштабе времени свойствен эволюционной сукцессии биосферы.

- Изменения в структуре биосферы, как и любой развивающейся системы, можно наблюдать путем сравнения сменяющих друг друга определенных состояний, наблюдаемых реально или в реконструированном виде «здесь и сейчас» (принцип хаэссеитас).

- Объединение этих состояний в единую эволюционную систему происходит за счет трендов или информационных каналов, которые также имеют свою структуру. Эволюционная система биосферы представляет собой сложное взаимодействие временных её состояний, формирующихся при передаче информации по информационным каналам или эволюционным трендам. Поскольку биосфера имеет иерархическую структуру, прямыми и обратными информационными связями объединены и все уровни организации, в совокупности образуя элементы или подсистемы эволюционной системы биосферы.

Ноосферогенез, переход в новое состояние биосферы есть процесс частичной смены экосистем сугубо природного характера антропогенными экосистемами. В силу единства как структуры биосферы, так и её эволюционных процессов ноосферогенез может происходить принципиально так же, как и процессы на предыдущих этапах её развития, т.е. с неизбежными кризисными явлениями и революционными перестройками. 


\section{Список литературы}

Айзатуллин Т.А., Лебедев В.Л., Хайлов К.М. (1979) Океан. Активные поверхности и жизнь. Л., Гидрометеоиздат, 192 с. [Ayzatullin T.A., Lebedev V.L., Khailov K.M. (1979) Ocean. The active surfaces and life. Leningrad, Gidrometeoizdat, 192 p. (in Russian)]

Алеев Ю.Г. (1986) Экоморфология. Киев, Наук. думка., 423 с. [Aleev Yu.G. (1986) Ecomorfology. Kiev, Naukova Dumka, 423 p. (in Russian)]

Алимов А.Ф., Богатов В.В., Голубков С.М. (2013) Продукционная гидробиология. СПб., Наука, 343 с. [Alimov A.F., Bogatov V.V., Golubkov S.M. (2013) Production Hydrobiology. St. Petersburg, Nauka, 343 p. (in Russian)]

Беклемишев В.Н. (1964) Об общих принципах организации жизни. Бюлл. МОИП. Отд. Биол., 69 (2): 22-38 [Beklemishev V.N. (1964) On general principles of organization of life. Bull. Moscow Society of Naturalists. Dep. Biol. [Byull. MOIP. Otd. Biol.], 69 (2): 22-38 (in Russian)]

Беклемишев В.Н. (1994) Методология систематики. Любарский Г.Ю. (ред.) М., KMK Scientific Press Ltd., 250 c. [Beklemishev V.N. (1994) Methodology of systematics. Lyubarskii G.Y. (ed.) Moskow, KMK Scientific Press Ltd., 250 p. (in Russian)]

Берг Л.С. (1947) Географические зоны Советского Союза. М., Гос. изд. географической литературы ОГИЗ, 397 с. [Berg L.S. (1947) Geografic zones of the Soviet Union. Moscow, Gos. izd. geograficheskoj literatury OGIZ, 397 p. (in Russian)]

Биологический энциклопедический словарь (1986) Гиляров М.С. (ред.) М., Советская энциклопедия, 831 с. [Biological Encyclopedic Dictionary (1986) Gilyarov M.S. (ed.) Moscow, Sovetskaya enciklopediya, 831 p. (in Russian)]

Бурковский И.В. (2006) Морская биогеоценология. Организаџия сообществ и экосистем. М., Т-во научн. изд. КМК, 285 с. [Burkovsky I.V. (2006) Marine biogeocenology. Organization of communities and ecosystems. Moscow, Tovarishchestvo nauch. izd. KMK, 285 p. (in Russian)]

Вальтер Г. (1975) Растительность Земного шара. Эколого-физиологическая характеристика. T. 3. Тундры, луга, степи, внетропические пустыни. М., Прогресс, 428 с. [Walter G. (1975) Vegetation of the Earth. Ecological and physiological characteristic. V. 3. Tundra, grasslands, prairies, extratropical deserts. Moscow, Progress, 428 p. (in Russian)]

Вернадский В.И. (2012) Биосфера. Вибрані наукові праиі академіка В.І.Вернадського. Т. 4. Кн. 1. Киев, с. 220-321 [Vernadsky V.I. (2012) Biosphere. Selected scientific works of academician V.I.Vernadsky. V.4, B.1. Kiev, p. 220-321 (in Russian)]

Вернадский В.И. (2012а) Биосфера и ноосфера. Вибрані наукові прачі академіка B.I.Вернадського. Т. 4., Кн. 2. Киев, с 453-465 [Vernadsky V.I. (2012a) Biosphere and noosphere. Selected scientific works of academician V.I.Vernadsky. V.4., B.2. Kiev, p. 453-465 (in Russian)]

Вернадский В.И. (2012б) Об условиях появления жизни на Земле. Вибрані наукові праці академіка В.І.Вернадського. Т. 4., Кн. 2. Киев, с. 318-334 [Vernadsky V.I. (2012b) Conditions for the emergence of life on Earth. Selected scientific works of academician V.I.Vernadsky. V.4, B. 2. Kiev, 318-334 (in Russian)]

Винер Н. (1958) Кибернетика или управление и связь в животном и машине. М., Советское радио, 215 с. [Viner N. (1958) Cybernetics or control and communication in the animal and the machine. Moscow, Sovetskoe radio, 215 p. (in Russian)] 
Гиляров А.М. (2007) Ариаднина нить эволюционизма. Вестник РАН, 77(6): 508-519 [Gilyarov A.M. (2007) Ariadna' thread of the evolutionism. Herald of Russian Academy of Sciences [Vestnik RAN], 77 (6): 508-519 (in Russian)]

Голубец М.А. (1983) Диалектика в науках о природе и человеке. Эволюция материи и её структурные уровни. Труды ІІІ Всесоюзного совещания по философским вопросам современного естествознания. М., Наука, с. 379-383 [Golubec M.A. (1983) Dialectic in the sciences of nature and man. The evolution of matter and its structural levels. Proceedings of III All-Union Conference on Philosophical Problems of Modern Natural Science. Moscow, Nauka, p. 379-383 (in Russian)]

Грант В. (1991) Эволюиионный процесс. М., Мир, 488 с. [Grant V. (1991) The evolutionary process. Moscow, Mir, 488 p. (in Russian)]

Дарвин Ч. (1907) Происхождение видов. Иллюстрированное собрание сочинений. Т.1. М., Издание Ю. Лепковскаго, 435 с. [Darwin Ch. (1907) The origin of species. Illustrated works. V.1. Moscow, Publ. Yu. Lepkovsky, 435 p. (in Russian)]

Дубина Д.В., Кордюм Є.Л. (2015) Пластичність онтогенезу судинних рослин: молекулярні, клітинні, популяційні та ценотичні аспекти. Вісник НАН України, 7: 32-39 [Dubina D.V., Kordyum E.L. (2015) Plasticity of ontogenesis of vascular plants: molecular, cellular, population and coenotic aspects. Herald of NAS of Ukraine, 7: 32-39 (in Ukrainian)]

Жерихин В.В. (1986) Биоценотическая регуляция эволюции. Палеонтологический журнал, 1: 3-12 [Zherikhin V.V. (1986) Biocenotic regulation of the evolution. Paleontological Journal [Paleontologicheskij zhurnal], 1: 3-12 (in Russian)]

Жерихин В.В. (2003) Избранные труды по палеоэкологии и филоценогенетике. М., Тов-во научн. изд. КМК, 542 c. [Zherikhin V.V. (2003) Selected works on paleoecology and filocenogenetics. Moscow, Tovarishchestvo nauch. izd. KMK, 542 p. (in Russian)]

Живое вещество и биосфера (1994) Вернадский В.И. М., Мысль, 672 с. [Living matter and the Biosphere (1994) Vernadsky V.I. Moscow, Mysl, 672 p. (in Russian)]

Заварзин Г.А. (1995) Анти-рынок в природе. Природа, 5: 46-60 [Zavarzin G.A. (1995) Antimarket in nature. Nature [Priroda], (5): 46-60 (in Russian)]

Заварзин Г.А. (2001) Становление биосферы. Вестник РAH, 71(11): 988-1001 [Zavarzin G.A. (2001) Development of biosphere. Herald of Russian Academy of Sciences [Vestnik RAN], 71(11): 988-1001 (in Russian)]

Заварзин Г.А. (2003) Лекциии по природоведческой микробиологии. М., Наука, 348 с. [Zavarzin G.A. (2003) Lectures on environmental microbiology. Moscow, Nauka, 348 p. (in Russian)]

Заварзин Г.А. (2003a) Антипод ноосферы. Вестник РАН, 73(7): 627-636 [Zavarzin G.A. (2003a) The antipode of the noosphere. Herald of Russian Academy of Sciences [Vestnik RAN], 73(7): 627-636 (in Russian)]

Заварзин Г.А. (2007) Ариаднина нить или паутина Арахны? Вестник РАH, 77(6): 11-13 [Zavarzin G.A. (2007) Ariadne's thread or web Arachne? Herald of Russian Academy of Sciences [Vestnik RAN], 77 (6): 11-13 (in Russian)]

Заварзин Г.А. (2007а) Бытие и развитие: эволюция, сукцессия, хаэссеитас. Вестник РАН, 77(4): 334-340 [Zavarzin G.A. (2007a) Genesis and development: evolution, succession, haesseitas. Herald of Russian Academy of Sciences [Vestnik RAN], 77 (4): 334-340 (in Russian)]

$$
-285-
$$


Зайцев Ю.П. (2015) О контурной структуре биосферы. Гидробиол. журн., 51(1): 3-27 [Zaitsev Yu.P. (2015) On the contour structure of the biosphere. Journal of Hydrobiology [Girobiologicheskij zhurnal], 51 (1): 3-27 (in Russian)]

Кафанов А.И. (2004) Континуальность и дискретность геомериды: биономический и биотический аспекты. Журнал общей биологии, 56(6): 486-512 [Kafanov A.I. (2004) The continuity and discontinuity of geomerida: bionomic and biotic aspects. Journal of General Biology [Zhurnal obshchei biologii], 56 (6): 486-512 (in Russian)]

Кафанов А.И. (2005) Историко-методологические аспекты общей и морской биогеографии. Владивосток, Изд-во Дальневост. ун-та, 208 с. [Kafanov A.I. (2005) Historical and methodological aspects of general and marine biogeography. Vladivostok, Far Eastern University, 208 p. (in Russian)]

Колчинский Э.И. (1990) Эволючия биосферы. Историко-критический очерк исследований в СССР. Л., Наука, 236 c. [Kolchinsky E.I. (1990) The evolution of the biosphere. Historical-critical essay on research in the USSR. Leningrad, Nauka, 236 p. (in Russian)]

Кордюм В.А. (1982) Эволюиия и биосфера. К., Наукова думка, 264 с. [Kordyum V.A. (1982) The evolution and the biosphere. Kiev, Naukova Dumka, 264 p. (in Russian)]

Красилов В.А. (1986) Нерешенные проблемы теории эволюиии. Владивосток, ДВНЦ АН CCCP, 125 c. [Krasilov V.A. (1986) Unsolved problems in the theory of evolution. Vladivostok, Far Eastern Scientific Center of the USSR Academy of Sciences, 125 p. (in Russian)]

Красилов В.А. (1992) Охрана природы: приниипы, проблемы, приоритеты. М., Институт охраны природы и заповедного дела, 173 с. [Krasilov V.A. (1992) Nature conservation: principles, problems and priorities. Moscow, Institute for the Conservation of Nature and Natural Reserves, $173 \mathrm{p}$. (in Russian)]

Кузнецов А.П. (1980) Экология донных сообществ Мирового океана (трофическая структура морской донной фауны). М., Наука, 244 с. [Kuznetsov A.P. (1980) Ekology of benthic communities of the world's oceans (trophic structure of marine benthic fauna). Moscow, Nauka, $244 \mathrm{p}$. (in Russian)]

Левченко В.Ф. (1992) Направленность биологической эволюции как следствие развития биосферы. Журнал общей биологии, 53(1): 58-70 [Levchenko V.F. (1992) The focus of biological evolution as a consequence of the development of the biosphere. Journal of General Biology [Zhurnal obshchei biologii], 53(1): 58-70 (in Russian)]

Левченко В.Ф. (2010) Происхождение жизни и биосферы - единый процесс. Tруды Международной научной конференции «Чарльз Дарвин и современная биология»; 21-23 сентября 20092., Санкт-Петербург. СПб., Нестор-История, с. 338-347 [Levchenko V.F. (2010) The origin of life and the biosphere - a single process. Proceedings of the International Scientific Conference "Charles Darwin and modern biology"; 21-23 September 2009; St. Petersburg. Petersburg, NestorIstoriya, p. 338-347 (in Russian)]

Левченко В.Ф. (2012) Биосфера: этапы жизни. СПб., Свое издательство, 264 с. [Levchenko V.F. (2012) Biosfere: stages of life. SPb., Svoe Izdatelstvo, 264 p. (in Russian)]

Лекявичус Э. (1986) Элементы общей теории адаптаций. Вильнюс, Мокслас, 273 c. [Lekyavichus E. (1986) Elements of general theory of adaptation. Vilnius, Mokslas, 273 p. (in Russian)] 
Лекявичус Э. (2003) Эволюция экосистем: основные этапы и возможные механизмы. Журнал общей биологии, 64(5): 371-388 [Lekyavichus E. (2003) Evolution of ecosystems: the main stages and possible mechanisms. Journal of General Biology [Zhurnal obshchei biologii], 64 (5): 371-388 (in Russian)]

Маргалеф Р. (1992) Облик биосферы. М., Наука, 214 с. [Margalef R. (1992) The appearance of the biosphere. Moscow, Nauka, 214 p. (in Russian)]

Маргалеф Р. (2011) Перспективы в экологической теории. Пер. с англ. А.Г. Розенберг, Г.С. Розенберга и Г.А. Шараева. Чл.-корр. РАН Г.С. Розенберг (ред.) Тольятти, ИЭВБ РАН, «Кассандра», 122 с. [Margalef R. (2011) Perspectives in ecological theory. Translated from English by Rosenberg A.G., Rosenberg G.S. and Sharaeva G.A. Rosenberg G.A. (ed.) Toliatti, IEVB RAS, «Cassandra», 122 p. (in Russian)]

Марков А.В., Коротаев А.В. (2008) Гиперболический рост разнообразия морской и континентальной биот фанерозоя и эволюция сообществ. Журнал общей биологии, 69(3): 175-194 [Markov A.V., Korotaev A.V. (2008) Hyperbolic growth of marine and continental Phanerozoic biota diversity and evolution of communities. Journal of General Biology [Zhurnal obshchei biologii], 69(3): 175-194 (in Russian)]

Ноосфера. Новая философская энциклопедия [The noosphere. New Encyclopedia of Philosophy] www.http://iph.ras.ru/elib/2117.html

Одум Ю. (1975) Основы экологии. М., Мир, 740 с. [Odum Е. (1975) Fundamentals of ecology. Moscow, Mir, 740 p. (in Russian)]

Переписка 2-х столии (2013) М., 168 с. [The correspondence of 2 capitals (2013) Moscow, 168 p. (in Russian)]

Пономаренко А.Г. (2007) Эволюция экосистем континентальных водоемов. Проблемьь водной энтомологии России и сопредельных стран. Воронеж, Изд. центр Воронеж. гос. унта, c. 228-259 [Ponomarenko A.G. (2007) Evolution of ecosystems of continental waters. Problems of aquatic entomology of Russia and neighboring countries. Voronezh State University, p. 228-259 (in Russian)]

Поярков Б.В., Бабаназарова О.В. (2003) Учение о биосфере: Курс лекций. Ярославль, Ярославский ун-т, 408 c. [Poyarkov B.V., Babanazarova O.V. The doctrine of the biosphere: Lectures. Yaroslavl, Yaroslavl University, 408 p. (in Russian)]

Протасов А.А. (2008) Биоразнообразие и его оценка. Концептуальная диверсикология. Киев, 105 с. [Protasov А.А. (2008) Biodiversity and its evaluation. Conceptual diversicology. Kiev, 105 p. (in Russian)]

Протасов А.А. (2011) Жизнь в гидросфере. Очерки по общей гидробиологии. Киев, Академпериодика, 704 с. [Protasov A.A. (2011) Life in the hydrosphere. Essays on general hydrobiology. Kiev, Akademperiodika, 704 p. (in Russian)]

Протасов А.А. (2012) Биогеом как структурная единица биосферы. Биосфера, 4(3): 280285 [Protasov A.A. (2012) Biogeome as a structural unit of the biosphere. Biosphere [Biosfera], 4(3): 280-285 (in Russian)]

Протасов А.А. (2013) О водных техноэкосистемах и их месте в биосфере. Журнал Сибирского федерального университета. Биология, 4(6): 405-423 [Protasov A.A. (2013) On the water techno-ecosystems and their role in the biosphere. Journal of Siberian Federal 
University. Biology [Zhurnal Sibirskogo federalnogo universiteta. Biologiya], 4(6): 405-423 (in Russian)]

Протасов А.А. (2013а) Макроструктура биосферы и место в ней биогеома. Биосфера, 5(4): 384-392 [Protasov A.A. (2013a) Macrostructure of biosphere and biogeome' place in it. Biosphere [Biosfera], 5(4): 384-392 (in Russian)]

Протасов А.А. (2014) О возможных механизмах ноосферогенеза. Биосфера, 6(3): 204-210 [Protasov A.A. (2014) On the possible mechanisms of noospherogenesis. Biosphere [Biosfera], 6(3): 204-210 (in Russian)]

Протасов А.А. (2014a) Концепция техно-экосистемы в технической гидробиологии. Гидробиол. журн., 50(3): 3-18 [Protasov A.A. (2014a) The concept of techno-ecosystem in technical hydrobiology. Journal of Hydrobiology [Girobiologicheskij zhurnal], 50(3): 3-18 (in Russian)]

Пучковский С.В. (2013) Эволючия биосистем. Факторы микроэволючии и филогенеза в эволюиионном пространстве-времени. 2-е изд., перераб. и доп. Ижевск, Изд-во «Удмуртский университет», 443 c. [Puchkovsky S.V. (2013) The evolution of biosystems. Factors of microevolution and phylogeny in the evolutionary space-time. 2nd ed. Izhevsk, Udmurtia University, 443 p. (in Russian)]

Разумовский С.М. (1999) Избранные трудыл. М., Тов-во научн. изд. КМК, 559 с. [Razumovsky S.M. (1999) Selected works. Moscow, Tovarishchestvo nauch. izd. KMK, 559 p. (in Russian)]

Риклефс Р. (1979) Основы общей экологии. М., Мир, 424 с. [Riklefs R. (1979) Fundamentals of general ecology. Moscow, Mir, 424 p. (in Russian)]

Руководство по Рамсарской конвенции. Справочник по осуществлению Конвенции о водноболотных угодьях (Рамсар, Иран, 1971 г.) (2006) 4-е изд. Гланд, Секретариат Рамсарской конвенции, 146 с. [Ramsar Guidelines. Implementation Handbook for the Convention on Wetlands (Ramsar, Iran, 1971) (2006) 4th ed. Gland, The Secretariat of the Ramsar Convention, 146 p. (in Russian)]

Руденко А.П. (2000) Самоорганизация и синергетика. Синергетика. Тр. семинара. Т. 3. М., Изд-во МГУ, с. 61-99 [Rudenko A.P. Self-organization and synergetics. Synergetics. Proc. seminar. V.3. Moscow, MSU, p.61-99 (in Russian)]

Савинов А.Б. (2012) Аутоценоз и демоценоз как симбиотические системы и биологические категории. Журн. общ. биол., 73(4): 284-301 [Savinov A.B. (2012) Autocenoses and democenosis as a symbiotic systems and biolological categories. Journal of General Biology [Zhurnal obshchei biologii], 73(4): 284-301 (in Russian)]

Северцов С.А. (1997) Эволюция популяций и эволюция биоценозов. Зоол. журн., 77(5): $517-$ 526 [Severtsov S.A. (1997) The evolution of populations and evolution of the biocenoses. Russian Journal of Zoology [Zoologicheskij zhurnal], 77(5): 517-26 (in Russian)]

Сукачев В.Н. (1972) Основные понятия лесной биоценологии. Избранные труды. T.1. Основы лесной типологии и биогеоиенологии. Л., Наука, с. 311-356 [Sukachev V.N. (1972) Concepts of forest phytocenology. Selected Works. V.1. Basics of forest typology and biogeocenology. Leningrad, Nauka, p. 311-356 (in Russian)]

Тахтаджян А.Л. (1998) Principia tektologica. Принцуипы организациии и трансформации сложных систем: эволюиионный подход. СПб., С.-Петерб. гос. хим.-фармацевт. акад., 117 с. [Takhtadzhyan A.L. (1998) Principia tektologica. Principles of organization and transformation of complex systems: an evolutionary approach. SPb., St. Petersburg. State. Chem.- Pharmaceut. Acad., 117 p. (in Russian)] 
Тимофеев-Ресовский Н.В., Тюрюканов А.Н. (1966) Об элементарных биохорологических подразделениях биосферы. Бюлл. МОИП. Отд. Биол., 71 (1): 123-132 [Timofeev- Resovskii N.V., Tyuryukanov A.N. (1966) On elementary biochorological divisions of biosphere. Bull. Moscow Society of Naturalists. Div. Biol. [Byull. MOIP. Otd. Biol.], 71(1): 123-132 (in Russian)]

Уиттекер Р. (1980) Сообщества и экосистемьл. М., Прогресс, 327 с. [Whittaker R. (1980) Communites and the ecosystems. Moscow, Progress, 327 p. (in Russian)]

Хайлов К.М., Празукин А.В., Ковардаков С.А., Рыгалов В.Е. (1992) Функииональная морфология морских многоклеточных водорослей. Киев, Наук. думка., 280 с. [Khailov K.M., Prazukin A.V., Kovardakov S.A., Rygalov V.E. (1992) Functional morphology of multicellular marine algae. Kiev, Naukova Dumka, 280 p. (in Russian)]

Хакен Г. (1980) Синергетика. М., Мир, 325 с. [Haken G. (1980) Synergetics. Moscow, Mir, 325 p. (in Russian)]

Шмальгаузен И.И. (1968) Факторы эволющии. Теория стабилизирующего отбора. М., Наука, 451 c. [Schmalhausen I.I. (1968) Factors of evolution. The theory of stabilizing selection. Moscow, Nauka, 451 p. (in Russian)]

Шмальгаузен И.И. (1968а) Кибернетические вопросы биологии. Новосибирск, Наука, 224 c. [Schmalhausen I.I. (1968a) Cybernetic questions of biology. Novosibirsk, Nauka, 224 p. (in Russian)]

Яблоков А.В., Левченко В.Ф., Керженцев А.С. (2015) Очерки биосферологии. 1. Выход есть: переход к управляемой эволюции биосферы. Философия и космология, 14: 92-117 [Yablokov A.V., Levchenko V.F., Kerzhentsev A.S. (2015) Essays of Biospherology. 1. There is a way: the transition to a managed evolution of the biosphere. Philosophy \& Cosmology [Filosofiya i kosmologiya], 14: 92-117 (in Russian)]

Ashby W.R. (1957) An introduction to cybernetics. 2nd edition. London, Chapmann and Hall LTD, $325 \mathrm{p}$.

Clements F.T., Shelford V.E. (1939) Bio-Ecology. N.Y., Wiley\&Sons, Inc., 425 p.

Evans F. (1956) Ecosystem as the basic unit of ecology. Sciense, 123: 1227-1228

Global Biodiversity Assessment (1995) Heywood V., Watson R. (eds.) Cambrige Univ. Press (UNEP), $1140 \mathrm{p}$.

Kolmakova O.V., Gladyshev M.I., Rozanov A.S., Peltek S.E, Trusova M.Yu. (2014) Spatial biodiversity of bacteria along the largest Arctic river determined by next-generation sequencing. FEMS Microbiology Ecology, 89(2): 442-450

Krassilov V.A. (2014) Evolution: System Theory. Sofia-Moscow, Pensoft, 414 p.

Lapenis A.G. (2002) Directed Evolution of the Biosphere: Biogeochemical Selection or Gaia? The Professional Geographer, 54(3): 379-391

Lashin S.A., Suslov V.V., Matushkin Yu.G. (2012) Theories of biological evolution from the viewpoint of the modern systemic biology. Russian Journal of Genetics, 48 (5): 481-496

Odum E. (1969) The strategy of ecosystem development. Sciense, 164: 262-270

Rosenberg E., Zilbert-Rosenberg I. (2009) The hologenome theory of evolution conteins Lamarckian aspects within Darwin framework. Environ.Microbiol., 11(12): 2959-2962.

Straskraba M. (1996) Lake and reservoir management. Verh. Internat. Verein. Limnol., 26, part 1: 193-209 
Tansley A.D. (1935) The use and abuse of vegetational concepts and terms. Ecology, 16(4): 284307

Thorson G. (1960) Parallel level-bottom communities, their temperature adaptation, and their "balance" between predators and food animals. Perspectives in Marine Biology. Univ. Californ. Press., 125 p.

Zaitsev Yu. (2012) Major accumulations of life and main "Pain points" in the seas and oceans. Journal of Environmental Science and Engineering, A1: 886-897 